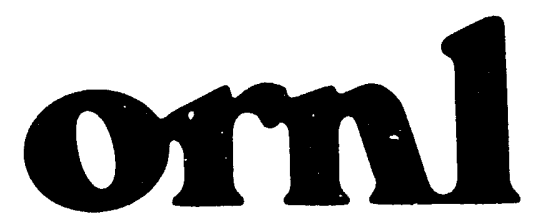

OAK RIDGE NATIONAL LABORATORY

MARTIN MARUETTA
Instrumentation and Controls Division Progress Report for the Period July 1,1988 to June 30,1990

Volume 2 
This report has been reproduced directly from the best available copy.

Available to DOE and DOE contractors from the Office of Scientific and Technical Information, P.O. Box 62, Oak Ridge, TN 37831; prices available from (615) 576-8401, FTS 626-8401.

Available to the public from the National Technical Information Service, U.S. Department of Commerce, 5285 Port Royal Rd., Springtield, VA 22161.

This report was prepared as an account of work sponsored by an agency of the United States Government. Neither the United States Government nor any agency thereot, nor any of their employees, makes any warranty, express or implied, or assumes any legal liability or responsibility for the accuracy, completeness, or usefulness of any information, apparatus, product, or process disclosed, or represents that its use would not infringe privately owned rights. Reference herein to any specific commercial product, process, or service by trade name, trademark, manufacturer, or otherwise, does not necessarily constitute or imply its endorsement, recommendation, or favoring by the United States Government or any agency thereof. The views and opinions of authors expressed herein do not necessarily state or reflect those of the United States Government or any agency thereof. 


\title{
INSTRUMENTATION AND CONTROLS DIVISION \\ Progress Report \\ for the Period July 1, 1988 to June 30, 1990
}

Volume 2

B. G. Eads, Director

LaWanda E. Y.lobe, Editor

1. Reactor Systems ....................... D. N. Fry, Section Head

2. Research Instruments ............... H. R. Brashear, Section Head

3. Measurement and Controls Engineering ....... D. W. McDona'd, Section Head

4. Maintenance Management ............. D. R. Miller, Department Head

Date Published-December 1990

\author{
Prepared by the \\ OAK RIDGE NATIONAL LABORATORY \\ Oak Ridge, Tennessee 37831 \\ managed by \\ MARTIN MARIETTA ENERGY SYSTEMS, INC. \\ for the \\ U.S. DEPARTMENT OF ENERGY \\ under contract DE-AC05-840R21400
}


Reports previously issued in this series are as follows:

\begin{tabular}{|c|c|}
\hline ORNL-714 & Period Ending April 15, 1950 \\
\hline ORNL-796 & Period Ending July 15, 1950 \\
\hline ORNL-924 & Period Ending October 31, 1950 \\
\hline ORNL-1021 & Period Ending January 20, 1951 \\
\hline ORNL-1056 & Period Ending April 20, 1951 \\
\hline ORNL-1159 & Period Ending July 20, 1951 \\
\hline ORNL-1160 & Period Ending October 20, 1951 \\
\hline ORNL-1335 & Period Ending January 20, 1952 \\
\hline ORNL-1336 & Period Ending April 20, 1952 \\
\hline ORNL-1389 & Period Ending July 20, 1952 \\
\hline ORNL-1436 & Period Ending October 20, 1952 \\
\hline ORNL-1492 & Period Ending 'anuary 20, 1953 \\
\hline ORNL-1694 & Period Ending July 31, 1953 \\
\hline ORNL-1749 & Period Ending January 31, 1954 \\
\hline ORNL-1768 & Period Ending July 31, 1954 \\
\hline ORNL-1865 & Period Ending January 31, 1955 \\
\hline ORNL-1997 & Period Ending July 31, 1955 \\
\hline ORNL-2067 & Period Ending January 31, 1956 \\
\hline ORNL-2234 & Period Ending July 31, 1956 \\
\hline ORNL-2480 & Period Ending July 1, 1957 \\
\hline ORNL-2647 & Period Ending July 1, 1958 \\
\hline ORNL-2787 & Period Ending July 1, 1959 \\
\hline ORNL-3001 & Period Ending July 1, 1960 \\
\hline ORNL-3191 & Period Ending July 1, 1961 \\
\hline ORNL-3378 & Period Ending September I, 1962 \\
\hline ORNL-3578 & Period Ending September 1, 1963 \\
\hline ORNL-3782 & Period Ending September 1, 1964 \\
\hline ORNL-3875 & Period Ending September 1, 1965 \\
\hline ORNL-4091 & Period Ending September 1, 1966 \\
\hline ORNL-4219 & Period Ending September 1, 1967 \\
\hline ORNL-4335 & Period Ending September 1, 1968 \\
\hline ORNL-4459 & Period Ending September 1, 1969 \\
\hline ORNL-4620 & Period Ending September 1, 1970 \\
\hline ORNL-4734 & Period Ending September 1, 1971 \\
\hline ORNL-4822 & Period Ending September 1, 1972 \\
\hline ORNL-4990 & Period Ending September 1, 1973 \\
\hline ORNL-5170 & Period Ending September 1, 1973 \\
\hline ORNL-5032 & Period Ending September 1, 1974 \\
\hline ORNL-5195 & Period Ending September 1, 1974 \\
\hline ORNL-5196 & Period Ending September 1, 1976 \\
\hline ORNL-5197 & Period Ending September 1, 1976 \\
\hline ORNL-5482 & Period Ending September 1, 1978 \\
\hline ORNL-5483 & Period Ending September 1, 1978 \\
\hline ORNL-5758 & Period Ending September 1, 1980 \\
\hline ORNL-5759 & Period Ending September 1, 1980 \\
\hline ORNL-5931/N1 & Period Ending July 1, 1982 \\
\hline ORNL-5931/V2 & Period Ending July 1, 1982 \\
\hline ORNL-6105/V1 & Period Ending July 1, 1984 \\
\hline ORNL-6308 & Period Ending July 1, 1986 \\
\hline & \\
\hline
\end{tabular}

NOTICE

Mention of brand names or of companies that supply products or services is made in this report for information purposes only and does not imply endorsement by the Oak Ridge National Laboratory, Martin Marietta Energy Systems, Inc., the U.S. Department of Energy, or any other organization. 


\section{VOLUME 1}

DIVISION OVERVIEW $\ldots \ldots \ldots \ldots \ldots \ldots \ldots \ldots \ldots \ldots \ldots \ldots \ldots \ldots$

\section{Section 1. Reactor System}

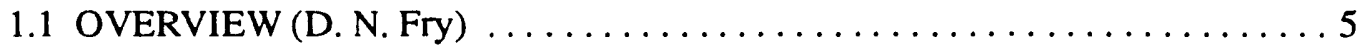

1.2 SUPERVISORY CONTROL RESEARCH $\ldots \ldots \ldots \ldots \ldots \ldots \ldots \ldots$

1.3 IMPROVED CONTROLLER FOR BABCOCK AND

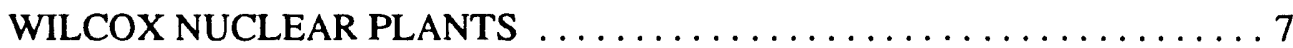

1.4 A FAST DYNAMIC ANALYSIS METHODOLOGY FOR DEVELOPMENT AND OPERATION OF CONTROLS FOR THE HEAVY WATER REACTOR/NEW PRODUCTION REACTOR $\ldots \ldots \ldots .8$

1.5 MODULAR HIGH-TEMPERATURE GAS-COOLED REACTOR/NEW PRODUCTION REACTOR SIMULATION USING PARALLEL PROCESSORS $\ldots \ldots \ldots \ldots \ldots \ldots \ldots \ldots \ldots$

1.6 DYNAMIC MODELING AS AN AID FOR DESIGN OF THE ADVANCED NEUTRON SOURCE REACTOR ..............9

1.7 HIGH-TEMPERATURE THERMOMETRY $\ldots \ldots \ldots \ldots \ldots \ldots \ldots \ldots$

1.8 SUBCRITICALITY MEASUREMENT SYSTEM FOR QUALITY CONTRUL AND DETERMINATION OF CRITICALITY SAFETY MARGINS $\ldots \ldots \ldots \ldots \ldots \ldots \ldots \ldots \ldots \ldots \ldots \ldots \ldots \ldots$

1.9 HIGH FLUX ISOTOPE REACTOR MONITORING AND

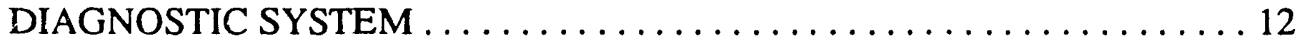

1.10 SURVEILLANCE OF SOLENOID-OPERATED VALVES $\ldots \ldots \ldots \ldots 13$

\section{Section 2. Research Instruments}

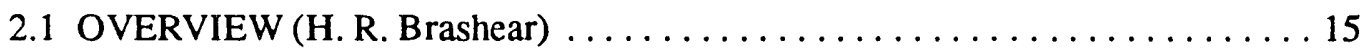

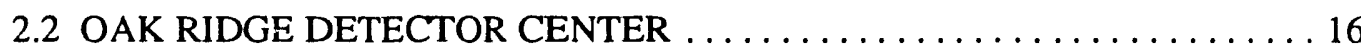

2.3 MODULAR ELECTROMAGNETIC LEVITATOR $\ldots \ldots \ldots \ldots \ldots \ldots$

2.4 SENSOR RESEARCH AND DEVELOPMENT $\ldots \ldots \ldots \ldots \ldots \ldots \ldots \ldots$

2.5 DROPLET CHARACTERIZATION OF THE LIQUID PHASE OF WET STEAM . . . . . . . . . . . . . . . . . . . . . . . . . 19

2.6 MONOLITHIC CIRCUIT DEVELOPMENT CAPABILITY

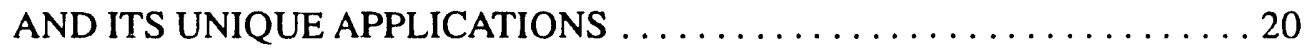

2.7 HEALTH PHYSICS INSTRUMENTATION UPGRADE SUPPORT . . . . . 21

2.8 RADIATION-HARDENED MICROWAVE COMMUNICATIONS SYSTEM 
2.9 MOTOR CURRENT DEMODULATION STUDIES

2.10 AUTOCALIBRATING VECTOR MAGNETOMETER

FOR HOSTILE ENVIRONMENTS $\ldots \ldots \ldots \ldots \ldots \ldots \ldots \ldots \ldots \ldots$

2.11 ULTRASONIC RANGING AND DATA SYSTEM $\ldots \ldots \ldots \ldots \ldots \ldots 24$

2.12 U.S. NAVY RADIAC DEVELOPMENT PROGRAM . . . . . . . . . . . 24

2.13 INTERACTIVE VIDEODISC INSTRUCTION PROTOTYPE . . . . . . 25

2.14 SYNCHRONOUS SCANNING LUMINOSCOPE $\ldots \ldots \ldots \ldots \ldots$

\section{Section 3. Measurement and Controls Engineering}

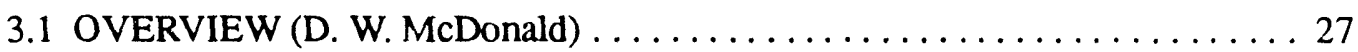

3.2 ADVANCED MANUFACTURING SYSTEMS $\ldots \ldots \ldots \ldots \ldots \ldots \ldots 28$

3.2.1 Metrology for Machining of Precision Optics $\ldots \ldots \ldots \ldots \ldots \ldots 28$

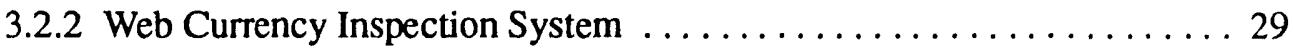

3.2.3 Postage Stamp Inspection Program $\ldots \ldots \ldots \ldots \ldots \ldots \ldots \ldots \ldots \ldots$

3.2.4 Y-12 Plant Computer-Automated Manufacturing $\ldots \ldots \ldots \ldots \ldots \ldots 32$

3.2.5 A Transportable, Knowledge-Based Assistant for

Troubleshooting Industrial Equipment $\ldots \ldots \ldots \ldots \ldots \ldots \ldots \ldots \ldots$

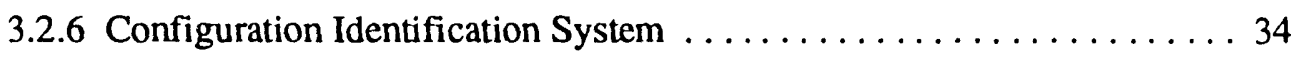

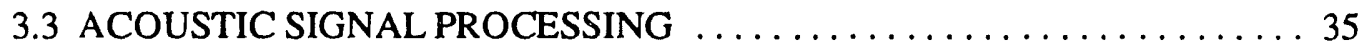

3.3.1 Multichannel Narrowband Noise Analysis System Extension . . . . . 35

3.3.2 The Sonar Signal Analysis System $\ldots \ldots \ldots \ldots \ldots \ldots \ldots \ldots \ldots$

3.3.3 Large Cavitation Channel Data Acquisition and Analysis System . . . . 36

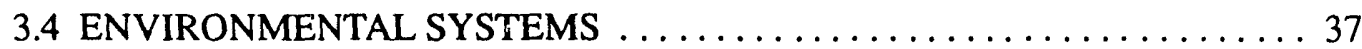

3.4.1 Ultraviolet-B Enhanced Exposure and Monitoring Facility . . . . . . 37

3.4.2 Personal Radio-Frequency Dosimeter $\ldots \ldots \ldots \ldots \ldots \ldots \ldots \ldots$

Section 4. Maintenance Management Department

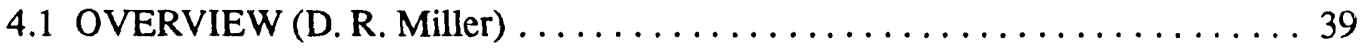

4.2 GENERAL FABRICATION CAPABILITY $\ldots \ldots \ldots \ldots \ldots \ldots \ldots \ldots$

4.3 AUTOMATIC VEHICLE AND PERSONNEL RADIOACTIVE CONTAMINATION MONITORING AND ALARM SYSTEM $\ldots \ldots \ldots \ldots 40$

4.4 PROGRAMMABLE MICROWAVE TEMPERATURE CONTROL . . . . . 40

4.5 TARGET PELLET FABRICATION SYSTEM $\ldots \ldots \ldots \ldots \ldots \ldots \ldots \ldots$ 


\section{Appendix}

PATENT APPLICATIONS FILED AND PATENTS ISSUED $\ldots \ldots \ldots \ldots \ldots 43$

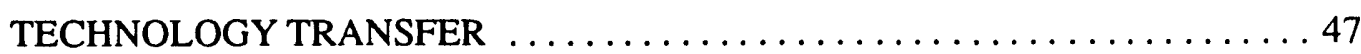

DIVISION ORGANIZATION CHART $\ldots \ldots \ldots \ldots \ldots \ldots \ldots \ldots \ldots \ldots$

\section{VOLUME 2}

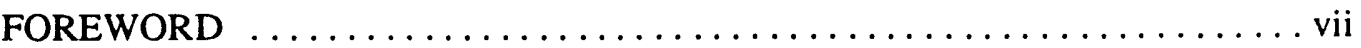

1. SUPPLEMENTARY ACTIVITIES $\ldots \ldots \ldots \ldots \ldots \ldots \ldots \ldots \ldots \ldots$

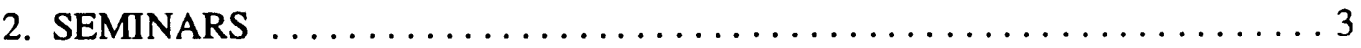

3. PUBLICATIONS AND PRESENTATIONS $\ldots \ldots \ldots \ldots \ldots \ldots \ldots \ldots$

3.1 Reactor Systems Section $\ldots \ldots \ldots \ldots \ldots \ldots \ldots \ldots \ldots \ldots \ldots \ldots \ldots \ldots \ldots \ldots \ldots \ldots \ldots$

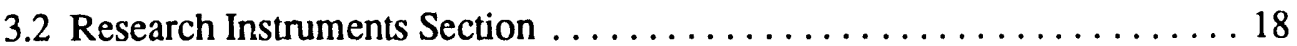

3.3 Measurement and Controls Engineering Section $\ldots \ldots \ldots \ldots \ldots \ldots 21$

3.4 Maintenance Management Department $\ldots \ldots \ldots \ldots \ldots \ldots \ldots \ldots 28$

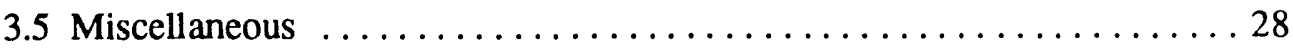

4. SCIENTIFIC AND PROFESSIONAL ACTIVITIES, ARCHIEVEMENTS,

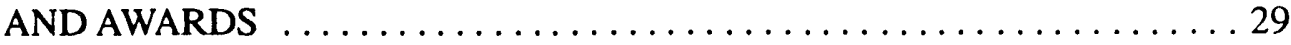

5. DIVISION ORGANIZATION CHARTS $\ldots \ldots \ldots \ldots \ldots \ldots \ldots \ldots \ldots \ldots$

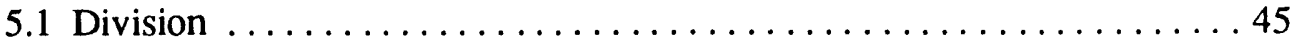

5.2 Reactor Systems Section $\ldots \ldots \ldots \ldots \ldots \ldots \ldots \ldots \ldots \ldots \ldots \ldots$

5.3 Research Instruments Section $\ldots \ldots \ldots \ldots \ldots \ldots \ldots \ldots \ldots \ldots \ldots$

5.4 Measurement and Controls Engineering Section ............... 48

5.5 Maintenance Management Department . . . . . . . . . . . . . . . 49

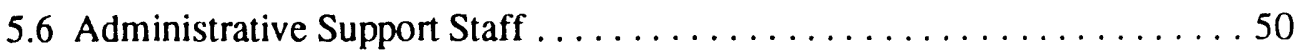


The format of this Instrumentation and Controls Division progress report is a major departure from previous reports. This report has been published in two volumes instead of one, and the descriptions of individual activities have been shortened considerably to make it an easier document to scan and to read.

Volume 1 of this report presents brief descriptions of a few highly significant programmatic and technological efforts representative of Instrumentation and Controls Division activities over the past two years. This volume contains information concerning the publications, presentations, and other professional activities and achievements of I\&C Division staff members. 


\section{SUPPLEMENTARY ACTIVITIES}

\section{SUPPLEMENTARY DIVISION ACTIVITIES}

The Instrumentation and Controls Division maintains liaison with industry and the academic community through its Advisory Committee and consultants, and through student and faculty research and training programs carried on within the Division.

\section{Advisory Committee-1990}

J. B. Ball, Director, Physics Division, Oak Ridge National Laboratory, Post Office Box X, Oak Ridge, TN 37831

Bindi Chexal, Electric Power Research Institute, 3412 Hillview Avenue, Palo Alto, CA 94303

Thomas B. Sheridan, Room 3-346, Department of Mechanical Engineering, Massachusetts Institute of Technology, Cambridge, MA 02139

Robert M. Taylor, Leeds \& Northrup, Sunneytown Pike, North Wales, PA 19454

\section{Division Consultants}

$\begin{array}{llll}\text { R. K. Adams } & \text { R. R. Feezell } & \text { C. D. Martin } & \text { R. W. Rochelle } \\ \text { A. Z. Akcasu } & \text { R. A. Finch } & \text { H. D. Miller } & \text { E. R. Rohrer } \\ \text { J. D. Allen } & \text { C. C. Goia } & \text { R. L. Moore } & \text { R. F. Saxe } \\ \text { S. C. Berridge } & \text { T. S. Hendry } & \text { C. A. Mossman } & \text { D. L. Senn } \\ \text { D. W. Bouldin } & \text { M. B. Herskovitz } & \text { E. C. Muly } & \text { G. V. Smith } \\ \text { D. Brzakovic } & \text { J. E. Hilger } & \text { W. P. Murray } & \text { J. D. Stanley } \\ \text { W. H. Casson } & \text { T. W. Kerlin } & \text { D. F. Newport } & \text { J. A. Thie } \\ \text { J. T. Conrad } & \text { D. B. Koch } & \text { D. J. Nypaver } & \text { L. Tsoukalas } \\ \text { R. W. Courtney } & \text { K. Korsah } & \text { W. W. Parkinson } & \text { R. W. Tucker, Sr. } \\ \text { P. B. Crilly } & \text { R. L. Lambert } & \text { R. A. Pavioti- } & \text { C. H. Weaver } \\ \text { R. L. DeWick } & \text { J. Lewin } & \text { Corcuera } & \text { D. K. Wehe } \\ \text { S. S. Devgan } & \text { B. Leinart, Jr. } & \text { G. V. S. Raju } & \text { S. J. Wertheimer } \\ \text { R. V. Dubey } & \text { B. Lieberman } & \text { M. H. Rashid } & \text { H. N. Wilson } \\ \text { W. H. Ellis } & \text { J. L. Lovvorn } & \text { W. B. Reese } & \text { R. W. Winks } \\ \text { J. A. Euler } & \text { F. W. Manning } & \text { E. A. Robinson } & \text { M. K. Wu } \\ \text { J. T. Farmer } & \text { J. H. Marable } & \text { J. M. Rochelle } & \end{array}$




\section{United Siates-Taiwan AIR/CCNNA Program for Nuclear Cooperation}

\section{Institute of Nuclear Energy Research}
H. J. Chen
C. H. Mao
Y. S. Chen
C. T. Tseng
C. H. King
C. M. Tsai
S. C. Lee
C. C. Tung
C. S. Luan
S. F. Wang

Taiwan Power Company
Y. H. Cheng
C. T. Shen

Atomic Energy Council
S. C. Chang
J. H. C. Wang

M. A. Abdalla

M. H. Abu-Shehadeh

I. E. Alguindigue

D. J. Auslander

M. Azar

R. C. Berkan

A. R. Bugos

R. L. Bywater, Jr.

L. G. Clonts

L. Driss

E. P. Ficaro

Z. Geng

\section{Graduate Students}
G. J. Gerst
M. L. Ganger
R. B. Gray, III
L. N. Guimaraes
R. D. Horn
J. G. Horner
M. Z. Ibn-Khayat
J. L. Llamas
R. B. Magness
C. March-Leuba
S. March-Leub?
G. V. Murphy
M. N. Natour
G. V. Rangarajan
L. A. Rovere
T. D. Robinson
B. S. Schwartz
A. Stolle
M. T. Travis
D. Ugoiini
A. H. Wu
H. M. Zghal

S. W. Milam

\section{Coop Students}
M. D. Allen
G. T. Appleton
R. J. Bastian
R. F. Baugh
J. D. Belcher
R. F. Bliss
C. E. Burton
W. R. Clem

D. E. Flinchum

F. B. Jones

T. F. Gee

M. R. Kedl

J. L. Hall

M. A. Kemper

F. B. Hedspeth, Jr.

E. M. King

C. A. Hendrich

L. J. Klaes, Jr.

D. M. Holmes

J. R. Lowery

D. L. Houser

C. W. Moyer

G. C. Howell

V. J. Myers

D. L. Page

J. S. Powell

C. L. Ricard

M. D. Smith

B. K. Swail

T. E. Talley

T. E. Valentine

M. E. Wyman 


\section{SEMINARS}

\section{SEMINARS PRESENTED OR SPONSORED BY INSTRUMENTATION AND CONTROLS DIVISION STAFF}

\footnotetext{
"An Alternative Approach to Control the Water Level of U-Tube Steam Generators," Carlos March-Leuba, Reactor Systems Section, March 2, 1989.

"Global Environmental Measurement Seminar," James R. Gosz, University of New Mexico, March 9, 1989.

“Engineering Anticipatory Systems,”' Lefteri Tsoukalas, University of Illinois, May 11, 1989.

"Neutron Noise Analysis, Vibration Analysis for Ensuring Mechanical Integrity, and Modeling of Vibrational Characteristics of RPV Internals," Volker Bauernfeind, Gesellschaft fur Reaktorsicherheit (GRS), Munich, Germany, August 4, 1989.
}

"Parity Simulation of Light Water Reactor Thermal Hydraulics," Eduardo V. Depiante, Massachusetts institute of Technology, August 21, 1989.

"Workshop on Neural Networks," Robert E. Uhrig, Organizer, November 20-21, 1989.

“Electromagnetic Levitation of Metallic Samples," R. J. Fox, Reactor Systems Section, December 6, 1989.

“ Discrete-Type of Sliding-Mode Control System Design,” Katsuhisa Furuta, Tokyo Institute of Technology, December 19, 1989.

"The Un-Simler: A DNA Sequencing Aid," Jack B. Davidson, Reactor Systems Section, January 31, 1990.

"The Role of Quantum Mechanics in Prescision Measurement," Norman F. Ramsey, Higgens Professor, Lyman Physics Lab, Harvard University, February 21, 1990.

"A Dynamic Model for the ANS Reactor and the Utilization of Optimal Control as a Diagnostic Tool," Mohammed Abu-Shehadeh, University of Tennessee, Knoxville, March 22, 1990.

“General System State Analysis,” Jack Mott, Engineering International, March 29, 1990.

Simulated Condensation: “An Auto-Adaptive Computer Learning Technique," Eric $B$. Bartlett, University of Tennessee, April 19, 1990. 
System Cultivation: "Process Monitoring and Control Using the Historical Data Base," Andrew Earl Farell, University of Tennessee, April 30, 1990.

"Pulsed Ionization Chamber Techniques for Nuclear Generated Plasma," Won Young Choi, University of Florida, May 14, 1990.

"Hypertext and Integration," Lefteri Tsoukalas, University of Tennessee, Knoxville, May 30, 1990.

"Application of Neural Network Technology in Reactor Surveillance Systems," Kofi Korsah, University of Tennessee, May 31, 1990.

"Syntactic Pattern Analysis and Expert System Integration for Valve Diagnostics," Jari Eklund, University of Tennessee, and Imatran Vorma Oy, Finland, June 22, 1990. 


\section{PUBLICATIONS AND PRESENTATIONS}

\subsection{Reactor Systems}

D. C. Agouridis, "Noise Performance of nperational Amplifier Circuits," IEEE Trans. Education (in press).

D. C. Agouridis, "Noise Thermometers for Hostile Environments: A Theoretical Evaluation," IEEE Trans. Instrum. Nioas. 39(5), 780-84 (October 1990).

D. C. Ago ur is and C. E. Easterly, "EMP Simulators and Public Safety: An Analysis," Bioelectromagnetics 10, 355-60 (Novemher 1989).

I. E. Alguindigue, E. Eryurek, B. R. Upahyaya, and R. E. Uhrig, "Using Artificial Neural Networks to Identify Nuclear Power Plant States," Trans. Am. Nucl. Soc. 61, 217-18 (June 1990).

I. E. Alguindi, -ue and R. E. Uhrig, "On the Identification of Nuclear Power Plant States Using the Polynomial Discriminant Method," Proc. Internat. Soc. Optical Eng.: Applications of Artificial Intelligence VIII, Vol. 1293, pp. 896-901 (1990).

J. L. Anderson, R. L. Anderson, E. W. Hagen, T. C. Morelock, T. L. Huang, and

L. E. Phillips, "Post-Implementation Review of Inadequate Core Cooling Instrumentation," IEEE Trans. Nucl. Sci. 36(1), 1248-50 (February 1989).

J. L. Anderson, E. W. Hagen, and T. C. Morelock, Summary of Inadequate Core Cooling Instrumentation for U.S. Nuclear Power Plants, NUREG/CR-5374, ORNI/TM-11200, Oak Ridge National Laboratory, Martin Marietta Energy Systems, Inc., July 1990.

S. J. Ball and J. C. Conklin, "Modular High-Temperature Gas-Cooled Reactor Core Heatup f.ccident Simulations," Proc. 1989 Eastern Simulation Councils Multiconf., 128-32 (1989).

S. I. Ball and J. C. Conklin, "Modular High-Temperature Gas-Cooled Reactor Simulation Using Parallel Processors," Proc. 7th Power Plant Dynamics, Control, and Testing Symp., Vol. 1, 8.01-8.07 (May 1989).

S. J. Ball and J. K. Munro, Jr., Advanced Control Test Operation (ACTC) Conceptual Design Report, ORNL/ACP/LTR-89/4, Oak Ridge National Laboratory, Martin Marietta Energy Systems, In: , Ju u, 1989. 
D. G. Barber, G. A. Cordes, J. M. Doster, R. M. Edwards, K. C. Gross, R. W. King, W. K. Lehto, R. W. Lindsay, A. K. Powers, R. Scott, Jr., J. D. Staffon, L. W. Ward, and J. D. White, "Tightly Coupled Simulation Utilizing the EBR-II LMR: A Real-Time Supercomputing and AI Environment," Internat. Conf. Supercomputing in Nuclear Application (SNA'90), Mito City, Ibaraki, Japan, March 12-16, 1990.

R. E. Battle, "Evaluation of Digital Fault-Tolerant Architectures," 1990 ANS Annual Meeting on Advances in Human Factors Research on Man-Computer Interactions: Nuclear and Beyond, Nashville, Tenn., June 10-14, 1990, pp. 173-77.

R. E. Battle, "Evaluation of Digital Fault-Tolerant Architectures for Nuclear Power Plant Control Systems," Proc. Topical Meeting on Advances in Human Factors on Man-Computer Interactions: Nuclear and Beyond, pp. 173-77 (1990).

R. E. Battle and G. K. Corbett, "Digital, Remote Control System for a 2-MW Research Reactor," IEEE Trans. Nucl. Sci. 36(1), 1265-72 (February 1989).

J. D. Bell, J. H. Harris, J. L. Dunlap, V. K. Pare, M. Murakami, and H. Kaneko, "Fluctuation Studies in ATF," 7th IAEA Internat. Workshop on Stellarators, Oak Ridge, Tenn., April 10-14, 1989.

R. C. Berkan, R. L. Bywater, and B. R. Upadhyaya, "Advanced Automation Concepts for Large-Scale Systems: Application to Nuclear Reactor Startup," IEEE Control Systems Magazine (in press).

R. C. Berkan and B. R. Upadhyaya, "Dynamic Modeling and Simulation of EBR-II Steam Generator," Proc. Seventh Power Plant Dynamics, Control and Testing Symp. Vol. 1, 40.01-40.15 (May 1989).

R. C. Berkan and B. R. Upadhyaya, Implementation of Multivariable Control Techniques with Application to Experimental Breeder Reactor II, ORNL/TM-11134, Oak Ridge National L aboratory, Martin Marietta Energy Systems, Inc., June 1990.

R. C. Berkan and B. R. Upadhyaya, "Modern Control Theory Applications to Liquid Metal Reactors," Proc. IEEE Southeastcon '89, 3, 1245 (1988).

R. C. Berkan and B. R. Upadhyaya, "Recovery of Process Variables in Time Delay Plant Dynamics," Trans. Am. Nucl. Soc. 60, 470 (1989).

R. C. Berkan, B. R. Upadhyaya, and R. A. Kisner, Low-Order Dynamic Modeling of the Experimental Breeder Reactor II, ORNL/TM-11161, Oak Ridge National Laboratory, Martin Marictta Energy Systems, Inc., July 1990.

R. C. Berkan, B. R. Upadhyaya, and R. A. Kisner, "Reconstructive Inverse Dynamics in Feedwater Control," Trans. Am. Nucl. Soc. 61, 313-14 (June 1990).

R. C. Berkan, B. R. Upadhyaya, R. B. Perez, and R. A. Kisner, "A New Nonlinear Reconstructive Control Approach Applied to the Axial Xenon Oscillation Problem in PWRs (Pressurized Water Reactors)," Proc. 7th Power Plant Dynamics, Control and Testing Symp., Vol. 2, pp. 77.01-77.18 (1989). 
E. D. Blakeman and J. March-Leuba, "A Parametric Analysis of Decay Ratio Calculations in a Boiling Water Reactor Model," Proc. Seventh Power Plant Dynamics, Control and Testing Symp., Vol. 1, pp. 42.02-42.09 (1989).

J. A. Boshers, I. E. Alguindigue, C. G. Burnett, and R. E. Uhrig, "Safety Review Advisor," Proc. EPRI Conf. Expert Systems Applications to the Electric Power Industry, 2, pp. 705-16 (1989).

C. R. Brittain, Development of a Decomposition Technique for Nonlinear Feedback Control of Large-Scale Systems, Ph.D. Dissertation, The University of Tennessec, Knoxville, 1990.

C. R. Brittain, P. J. Otaduy, and R. B. Perez, Development of a General Learning Algorithm with Applications in Nuclear Reactor Systems, ORNL/TM-10650, Oak Ridge National Laboratory, Martin Marietta Energy Syste

ms, Inc., December 1989.

C. R. Brittain, P. J. Otaduy, L. A. Rovere, and R. B. Perez, "A New Approach to Hierarchical Decomposition of Large Scale Systems," Proc. Third IEEE Internat. Symp. Intelligent Control, pp. 108-12 (1989).

C. R. Brittain, L. A. Rovere, and P. J. Otaduy, "Implementation of a Control System Test Environment in UNIX," Proc. Canadian Nucl. Soc. Third Internat. Conf. Simulation Methods, Vol. 1, pp. 36-55 (1990).

E. R. Broadaway, L. C. Williams, J. A. Mullens, W. L. Zabriskie, and A. G. Roberts, "Troubleshooting Complex Systems--An Expert System, Interactive Video, Transportable PC Solution," Society for Applied Learning Technology, 5th Annual Conf. Applications of Artificial Intelligence and CD-ROM in Education \& Training, Arlington, Va., August 23-25, 1989.

M. E. Buchanan, O. C. Cole, R. W. Jones, and D. J. Marshall, Electromagnetic Pu!se Survey of the FEMA Federal Regional Center, Thomasville, Ga., ORNL/FEMA-88/1, Oak Ridge National Laboratory, Martin Marietta Energy Systems, Inc., February 1989.

M. E. Buchanan, O. C. Cole, R. W. Jones, and D. J. Marshall, Electromagnetic Pulse Survey of the Kentucky State Emergency Operating Center, Frankfort, Kentucky, ORNL/FEMA-89/1, Oak Ridge National Laboratory, Martin Marietta Energy Systems, Inc., September 1988.

R. L. Bywater, B. R. Upadhyaya, R. C. Berkan, and R. A. Kisner, "Command Validation of Secondary EM Pump System in the EBR-II," Trans. Am. Nucl. Soc. 62, 412-13, November 1990.

B. A. Carreras, N. Dominguez, J. N. Leboeuf, V. E. Lynch, L. A. Charlton, J. H. Harris, M. Murakasmi, J. D. Bell, V. K. Pare, and J. L. Dunlap, "Access to Second Stability in ATF," Sherwood Theory Meeting, San Antonio, Texas, April 3-5, 1989.

B. A. Carreras, N. Dominguez, J. N. Leboeuf, V. E. Lynch, L. A. Charlton, J. H. Harris, M. Murakami, J. D. Bell, V. K. Pare, and J. L. Dunlap, "Magnetic Fluctuations and Access to Second Stability in ATF," Sherwood Theory Meeting, San Antonio, Texas, April 3-5, 1989. 
B. A. Carreras, N. Dominguez, J. N. Leboeuf, V. E. Lynch, L. A. Charlton, J. H. Harris, M. Murakami, J. D. Bell, V. K. Pare, and J. L. Dunlap, "Magnetic Fluctuations and Access to Second Stability in ATF," Workshop on Intemal Magnetic Structure, Austin, Texas, February 22-24, 1989.

B. A. Carreras, J. H. Harris, M. Murakami, N. Dominguez, J. N. Leboeuf, L. A. Charlton, J. D. Bell, V. K. Pare, and J. L. Dunlap, "Access to the Second Stability Regime in ATF," Kyoto University, Kyoto, Japan, May 12-14, 1989.

D. G. Carroll, Y. Dayal, and J. D. White, "Plant Control Technology for the U.S. Advanced Liquid Metal Reactor (ALMR)," Enlarged Halden Program Group Meeting on Computerized Man Machine Communication, Bolkesjo, Norway, February 11-16, 1990.

R. J. Carter and R. E. Uhrig, Human Factors Issues Associated with Advanced Instrumentation and Controls Technologies in Nuclear Plants, NUREG/CR-5439, ORNL/TM-11319, Oak Ridge National Laboratory, Martin Marietta Energy Systems, Inc., June 1990.

R. J. Carter and R. E. Uhrig, "Human Factors Issues Related to Expert Systems for Electric Power Plants," EPRI Seminar, Orlando, Fla., June 5-8, 1989; Proceedings, Hemisphere Pub. Corp. (1990).

N. E. Clapp, Jr., "Data Acquisition and Signal Analysis for Maintenance," Digital Signal Acquisition and Processing for NDE \& Plant Maintenance Workshop, Charlotte, N.C., July 31-August 3, 1990.

N. E. Clapp, Jr., Hybrid Neural Network and Conventional Digital Signal Processing for Stationary and Transient Signature Recognition, ORNL/M-719, Oak Ridge National Laboratory, Martin Marietta Energy Systems, Inc., 1989.

B. Damiano, "Force Analysis of the Advanced Neutron Source Control Rod Drive Mechanism," IEEE Trans. Nucl. Sci. 37(3), 1415-23 (June 1990).

B. Damiano and R. C. Kryter, Current Applications of Vibration Monitoring and Neutron Noise Analysis to Detect and Diagnose Structural Degradation of Reactor Vessel Internals Resulting from Operational Aging, NUREG/CR-5479, ORNL/TM-11398, Oak Ridge National Laboratory, Martin Marietta Energy Systems, Inc., February 1990.

B. Damiano and J. March-Leuba, "Power Distribution Effects on Boiling Water Reactor Stabiity," Trans. Am. Nucl. Soc. 60, 480-81 (1989).

B. Damiano, J. March-Leuba, and J. A. Euler, "Application of Galerkin's Method for Calculating Boiling Water Reactor Limit-Cycle Amplitude Using the LAPUR Feedback Transfer Function and the Point Kinetics Equations," International Workshop on BWR Stability, Brookhaven National Laboratory, Upton, N.Y., October 18, 1990.

B. Damiano, J. March-Leuba, and J. A. Euler, "Calculation of BWR Limit Cycle Amplitude Using Galerkins' Method," Trans. Am. Nucl. Soc. 62, 296-97 (1990).

B. Damiano and J. A. Thie, "Noise Data Management Using Commerically Available Database Software," Trans. Am. Nucl. Soc. 57, 319-21 (1988). 
J. B. Davidson, "Instrumentation Development for Molecular Biology," U.S. DOE Human Genome Program, Contractor/Grantee Workshop, Santa Fe, N.M., November 3-4, 1989.

J. B. Davidson, "TV-Based Neutron Detectors," DOE/DMS Discussion Mecting on Neutron Scattering, Gatlinburg, Tenn., May 14-16, 1990.

J. B. Davidson, H. G. Smith, and R. A. Willems, "A Neutron-Sensitive Image Intensifier-Television System," 3rd World Conference on Neutron Radiography, Osaka, Japan, May 14-18, 1989.

C. S. Daw, W. F. Lawkins, D. J. Downing, and N. E. Clapp, Jr., "Chaotic Characteristics of a Complex Gas-Solids Flow," Phys. Rev. A, Third S :ries, 41(2), 1179-81 (January 1990).

D. M. Eissenberg, H. D. Haynes, and R. C. Kryter, "Non-Intrustive Condition Monitoring of Motor-Operated Valves Based on Motor Current Signature Analysis," Internat. Conf. Valves for Power Plants: Development and Testing, London, April 4-6, 1989.

D. D. Falter, G. T. Alley, K. G. Falter, J. M. Rochelle, K.H. Valentine, R. D. Westbrook, G. E. Jellison, Jr., and P. H. Fleming, "Development of a Solar-Powered Infrared Injection Laser Microminiature Transmitting System," Proc. Internat. Conf. on LASERS 1989, pp. 1081-87 (1989).

D. N. Fry, "Summary of the Fourth Conference on United States Utility Experience in Reactor Noise Analysis," SMORN V Symposium on Reactor Noise, Minich, Federal Republic of Germany, October 12-16, 1987, Prog. Nucl. Energy 21, 475-78 (1988).

A. Gacem, A. Maren, and R. E. Uhrig, "A Neural Network to Extract Implicit Knowledge from a Nuclear Data Base," Trans. Amer. Nucl. Soc. 62, 129 (November 1990).

W. H. Griest, R. A. Jenkins, B. A. Tomkins, J. H. Moneyhun, R. H. Ilgner, T. M. Gayle, C. E. Higgins, and M. R. Guerin, Sampling and Analysis of Diesel Engine Exhaust and the Motor Pool Workplace Atmosphere, Final Report, ORNL/TM-10689, Oak Ridge National Laboratory, Martin Marietta Energy Systems, Inc., 1988.

L. Guimaraes and R. E. Uhrig, "A Neural Network Application to Control a Nuclear Reactor," Trans. Am. Nucl. Soc. 61, 216-17 (June 1990).

Z. Guo and R. E. Uhrig, "Use of Neural Network in an Expert System to Enhance Nuclear Power Plant Safety," Trans. Am. Nucl. Soc. 61, 215-16 (June 1990).

P. J. Halsey, L. D. Duncan, A. F. Huntley, J. K. Munro, Jr., and A. F. Twitty, Cooperative Processing Feasibility for SNAP-II, ORNL/DSRD-9, Oak Ridge National Laboratory, Martin Marietta Energy Systems, Inc., June 1988.

J. H. Harris, J. D. Bell, J. L. Dunlap, H. Kaneko, and V. K. Pare, "Fluctuation Studies for ATF," 30th Annual Meet. Am. Phys. Soc., Div. Plasma Phys., Hollywood, Fla., October 31November 4, 1988.

J. H. Harris, J. D. Rell, J. L. Dunlap, H. Kaneko, and V. K. Pare, Fluctuation Studies for ATF, Bull. Am. Phys. Soc. 33, 2070 (1988).

J. H. Harris, V. K. Pare et al., "Second Stability in the ATF Torsatron," Phys. Rev. Lett. (1989). 
J. H. Harris, V. K. Pare et al., "Second Stability Studies in ATF," 7th IAEA Internat. Workshop on Stcllarators, Oak Ridge, Tenn., April 10-14, 1989.

F. X. Hartmann, K. K. Garcia, J. K. Munro, Jr., and D. W. Noid, "Dynamics of Coupled Electron-Nucleon Motion in a Laser Field," Proc. 3rd Internat. Laser Science Conf. (ILS-III), Am. Inst. Phys. 172, p. 756 (1988).

H. D. Haynes and R. C. Kryter, "Condition Monitoring of Machinery Using Motor Current Signature Aralysis," Proc. Ist Internat. Machinery Monitoring and Diagnostic Conf., pp. 690-95 (1989).

H. D. Haynes, R. C. Kryter, B. K. Stewart, "Use of Motor Current Signature Analysis at the EPRI M\&D Center," Fourth Incipient Failure Detection Conference Predictive Maintenance for the 90s, Philadelphia, Pa., October 15-17, 1990.

M. Ibn-Khayat, J. March-Leuba, and H. L. Dodds, "Advanced Neutron Source Reactor Dynamics Calculations: Comparison with SPERT-II Experimental Results," Trans. Am. Nucl. Soc. 60, 435-36 (1989).

M. Ibn-Khayat, J. March-Leuba, and H. L. Dodds, "Spert-II Benchmarks of a Dynamic Model for the Advanced Neutron Source Reactor," IEEE Trans. Nucl. Sci. 37(3) 1411-14 (1990).

R. A. Jenkins, W. H. Griest, J. H. Moneyhun, B. A. Tomkins, R. H. Igner, C. E. Higgins, and T. M. Gayle, "Sampling and Chemical Characterization of Workplace Atmospheres Contaminated with Airborne Diesel Exhaust" Proc. EPA/APCA Internat. Symp. Measurement of Toxic and Related Air Pollutants, pp. 119-30 (1988).

R. A. Jenkins, J. H. Moneyhun, T. M. Gayle, J. D. Lore, and R. H. Ross, Problem Definition Study on Techniques and Methodologies for Evaluating the Chemical and Toxicological Properties of Combustion Products of Gun Systems, Vol. 2: Facility Criteria for the Chemical and Toxicological Characterization of Gun Exhaust, Final Report, ORNL-6334/V2, Oak Ridge National Laboratory, Martin Marietta Energy Systems, Inc., January 1989.

R. A. Jenkins, J. H. Moneyhun, T. M. Gayle, and R. H. Ross, "Chemical and Toxicological Propertics of the Combustion Products of Rifle and Gun Systems," Pulmonary Research Review and Analysis, Aurora, Colo., September 20-22, 1988.

R. A. Kisner, "Automated Start-Up of EBR-II: A Preview," Proc. IAEA Specialist's Meeting on Advanced Control for Fast Reactors, pp. 2-100-2-118, IAEA No. IWGFR/71 (1989).

R. A. Kisner, "Fault-Tolerant Architecture Design," Instrumentation and Controls Strategies for Power Plants, NSAC/153, Vol. 1, August 1990.

R. A. Kisner, R. C. Berkan, and B. R. Upadhyaya, "Performance Characteristics for Advanced Control Systems," Proc. 7th Power Plant Dynamics, Control, and Testing Symp., pp. 4.01-4.13 (1989).

R. A. Kisner, R. J. Carter, and R. W. Lindsay, "Issues of Integrating High-Tech Concepts into Nuclear Power Plant Operation," Proc. 1990 ANS Annual Meeting on Advances in Human Factors Research on Man-Computer Interactions: Nuclear and Beyond, pp. 295-303 (1990). 
R. C. Kryter, "A Nonintrusive Method for Measuring the Operating Temperature of a Solenoid-Operated Valve," EPRI Conf. Monitoring Equipment Environments During Nuclear Plant Operation, Baltimore, Md., April 10-11, 1990.

R. C. Kryter, "Assessment of Nonintrusive Methods for Monitoring the Operational Readiness of Solenoid-Operated Valves," Proc. Sixteenth Water Reactor Safety Information Meeting, Vol III, pp. 399-409 (March 1989).

R. C. Kryter, "Nonintrusive Methods for Monitoring the Operational Readiness of Solenoid-Operated Valves," Nucl. Eng. Design 118(3), 409-17 (April 1990).

R. C. Kryter and H. D. Haynes, "Condition Monitoring of Machinery Using Motor Current Signature Analysis," Proc. 7th Power Plant Dynamics, Control, and Testing Symp., 2, pp. 84.01-84.21 (1989).

R. C. Kryter and H. D. Haynes, "Condition Monitoring of Machinery Using Motor Current Signature Analysis," Sound and Vibration 23(9), 14-21 (September 1989).

R. C. Kryter and H. D. Haynes, "How to Monitor Motor-Driven Machinery by Analyzing Motor Current," Power Engineering 93(10), 35-39 (October 1989).

C. March-Leuba, Study and Development of Advanced Control Techniques for Nuclear Reactors and Robots, ORNL/TM-11238, Oak Ridge National Laboratory, Martin Marietta Energy Systems, Inc., August 1989.

C. March-Leuba, "Study and Development of Advanced Control Techniques for Nuclear Reactors and Robots," Ph.D. Dissertation, The University of Tennessee, Knoxville, 1988.

C. March-Leuba and J. March-Leuba, "An Adaptive Nonlinear Filtering Algorithm for Optimal State Estimation of Nonlinear Nuclear Reactors," 1988 IEEE Nuclear Science Symposium, Orlando Fla., November 9-11, 1988.

C. March-Leuba, J. March-Leuba, and R. B. Perez, "Optimal Filtering, Parameter Tracking and Control of Nonlinear Nuclear Reactors," Proc. 1988 Internat. Reactor Physics Conf., Vol. IV, pp. 207-14 (1989).

C. March-Leuba, J. March-Leuba, and T. Wilson, "A New Approach to Controlling the Water Level of U-Tube Steam Generators," 1989 Nuclear Science Symposium, San Francisco, Calif., January 24-26, 1990.

C. March-Leuba, J. March-Leuba, and T. Wilson, "Automatic Water Level Control of U-Tube Steam Generators for Low Power Operation," IEEE Nuclear Science Symposium, San Francisco, Calif., January 24-26, 1990.

C. March-Leuba and R. B. Perez, Adaptive Optimal Control of Uncertain Nonlinear Systems: On-Line Microprocessor-Based Algorithm to Control Mechanical Manipulators, ORNL/TM-10764, Oak Ridge National Laboratory, Martin Marietta Energy Systems, Inc., May 1988.

C. March-Leuba and R. B. Perez, "Optimal Control of Uncertain Nonlincar Systems: An Application to a Two-Link Robotic Arm," 27th IEEE Conf. Decision and Control, Austin, Tex., December 7-9, 1988. 
J. March-Leuba, "Radial Nodalization Effects on BWR Stability Calculations," International Workshop on Boiling Reactor Stability, Brookhaven National Laboratory, Upton, N.Y.,

October 17-19, 1990.

J. March-Leuba, Review of NUFREQ-NPW and the Stability Methodology Proposed by Asea Brown Boveri, ORNL/NRC/LTR-90/15, Oak Ridge National Laboratory, Martin Marietta Energy Systems, Inc., August 1990.

J. March-Leuba, "Introduction to BWR Stability Phenomena," ACRS T/H Phenomena Subcommittee Meeting, Washington, D.C., April 27, 1990.

J. March-Leuba, "Status of ORNL Stability Efforts in Behalf of NRR," ACRS T/H Phenomena Subcommittee Meeting, Washington, D.C., April 27, 1990.

J. March-Leuba, Review of the ANNA (Advanced Neutron Noise Analysis) Software System for Boiling Water Reactor Stability Measurements and Its Implementation in WNP-2,

ORNL/NRC/LTR-90/7, Oak Ridge National Laboratory, Martin Marietta Energy Systems, Inc., February 1990.

J. March-Leuba, LAPUR Benchmark Against In-Phase and Out-of-Phase Stability Tests, ORNL/NRC/LTR-90/6, Oak Ridge National Laboratory, Martin Marietta Energy Systems, Inc., January 1990.

J. March-Leuba, "Stability of the Boiling Water Reactor Limit Cycle: Bifurcations and Chaotic Behavior," Trans. Am. Nucl. Soc. 60, 345-46 (1989).

J. March-Leuba, "Average Power Increase During Limit Cycle Oscillations," Trans. Am. Nucl. Soc. 60, 481-82 (1989).

J. March-Leuba, "Nonlinear Dynamics and Chaos in Boiling Water Reactors," Proc. NATO Advanced Workshop on Nonlinear and Stochastic Phenomena in Nuclear Systems, 192. pp. 371-85 (1989).

J. March-Leuba, "Understanding the Boiling Water Reactor Limit Cycle," Proc. BWR Stability Symp., pp. 20101-11 (August 1989).

J. March-Leuba, An Overview of BWR Stability Issues, ORNL/NRC/LTR-88/06, Oak Ridge National Laboratory, Martin Marietta Energy Systems, Inc., July 1988.

J. March-Leuba and M. Ibn-Khayat, "Dynamic Modeling of the Advanced Neutron Source Reactor," Trans. Am. Nucl. Soc. 61, 386-88 (1990).

J. March-Leuba and B. Damiano, S squehanna-2 Stability Measurements During Cycle 3, ORNL/NRC/LTR-90/3, Oak Ridge National Laboratory, Martin Marietta Energy Systems, Inc., January 1990.

J. March-Leuba and E. D. Blakeman, Out-of-Phase Instabilities in Boiling Water Reactors, ORNL/NRC/LTR-90/5, Oak Ridge National Laboratory, Martin Marietta Energy Systems, Inc., March 1990.

J. March-Leuba and E. D. Blakeman, Review of the ANNA (Advanced Neutron Noise Analysis) Software System for Boiling Water Reactor Stability Measurements, ORNL/NRC/LTR-88/7, Oak Ridge National Laboratory, Martin Marictta Energy Systems, Inc., March 1989. 
J. March-Leuba and E. D. Blakeman, "A Study of Out-of-Phase Power Instabilitics in Boiling Water Reactors," Proc. 1988 Internat. Reactor Physics Corf., pp. $465-73$ (1988).

J. March-Leuba and C. March-Leuba, "A Transient Reactivity Monitor Based on Optimal Control Theory," 1988 IEEE Nuclear Science Symposium, Orlando, Fla., November 9-11, 1988.

L. C. Maxey and T. V. Blalock, Optimizing the Temperature Compensation of an Electronic Pressure Measurement System, ORNL/TM-11262, Oak Ridge National Laboratory, Martin Marietta Energy Systems, Inc., August 1990.

J. T. Mihalczo, "Development of Portable Subcriticality Measurement System for Spent Fuel Shipping and Transportation Casks," Proc. Workshop on the Use of Burnup Credit in Spent Fuel Transport Casks, February 1988; Sandia Report SAND 89-0018, 285-301, 1989.

J. T. Mihalczo, "The ${ }^{252}$ Cf Noise Analysis Method for In-Plant Criticality Safety," Trans. Am. Nucl. Soc. 57, 334-35 (1988).

J. T. Mihalczo and E. D. Blakeman, "Safer Fuel Loading and Initial Reactor Startup Using the ${ }^{252}$ Cf Source Driven Noise Analysis Method," Trans. Am. Nucl. Soc. 61, 244-47 (1990).

J. T. Mihalczo, E. D. Blakeman, and V. K. Pare, "Detector Effects in ${ }^{252}$ Cf Source Driven Noise Analysis Measurements," Proc. Am. Nucl.Soc. Top. Mtg. Safety Margins in Criticality Safety, 24-30 (1989).

J. T. Mihalczo, E. D. Blakeman, and V. K. Pare, "Subcriticality of Two Uranyl Nitrate Slab Tanks Spaced in Air by the ${ }^{252}$ Cf-Source-Driven Noise Analysis Method," Proc. Top. Mtg. Safety Margins in Criticality Safety, Trans. Am. Nucl. Soc. 120-25 (1989).

J. T. Mihalczo, E. D. Blakeman, and G. E. Ragan, " ${ }^{252}$ Cf-Source-Driven Noise Analysis Measurements for Six Interacting Safe Bottles of Aqueous Uranyl Nitrate," Trans. Am. Nucl. Soc. 57, 133-34 (1988).

J. T. Mihalczo, E. D. Blakeman, G. E. Ragan, E. B. Johnson, and Y. Hachiya, "Dynamic Subcriticality Measurements Using the ${ }^{252}$ Cf-Source-Driven Neutron Noise Method," Nucl. Sci. Eng. 104, 314-38 (1990).

J. T. Mihalczo, E. D. Blakeman, G. E. Ragan, R. C. Kryter, H. Seino, and R. C. Robinson, ${ }^{252} \mathrm{Cf}$-Source Driven Noise Measurements of Subcriticality for a Slab Tank of Aqueous Pu-U Nitrate," Nucl. Technol. (in press).

J. T. Mihalczo, N. W. Hill, E. D. Blakeman, and V. K. Pare, "Detection System Characteristics Using ${ }^{252} \mathrm{CF}$ Ionization Chambers," 7th Symp. Radiation Measurements and Applications, University of Michigan, Ann A:bor, May 21-24, 1990.

J. T. Mihalczo and W. T. King, "Quality Assurance Verification of High-Flux Isotope Reactor Fuel Elements by the ${ }^{252}$ Cf-Source-Driven Noise Analysis Method," Nucl. Tech. 84, 205-23 (1989).

J. T. Mihalczo, G. E. Ragan, and E. D. Blakeman, "A Portable Measurement System for Subcriticality Measurements by the Cf-Source-Driven Neutron Analysis Method," IEEE Trans. Nucl. Sci. 35(1), 912-13 (1988). 
P. K. Mioduszewski, V. K. Pare et al., "Initial Operation and Edge Plasma Studies in ATF," 8th Internat. Conf. Plasma Surface Interactions in Controlled Fusion Devices, Juelich, Federal Republic of Germany, May 2-6, 1988.

J. H. Moneyhun, T. M. Gayl^, and R. A. Jenkins, Chemical Characterization and Toxicological Evaluation of Airborne Mixtures: A System for Gererating Mixed Aerosols from a Petroleum Based Liquid and a Fine Solid. ORNL/TM-11151, Oak Ridge National Laboratory, Martin Marietta Energy Systems, Inc., 1989.

J. H. Moneyhun, T. M. Gayle, and R. A. Jenkins, "A Laboratory Scale Liquid-Solid Smoke Generator to Simulate the XM55 Field System," Proc. Smoke/Obscurants Symposium XII, 1 , pp. 249-60 (1988).

J. A. Mullens, L. C. Williams, and W. L. Zabriskie, "An Integrated Diagnostic System for a Process Controller," Proc. Ist Internat. Machinery Monitoring and Diagnostic Conf., pp. 45-49, Library of Congress Catalog No. 89-51139 (September 1989).

M. Murakami, V. K. Pare et al., "Second Stability Studies in the ATF Torsatron," 16th European Conf. ou Controlled Fusion and Plasma Physics, Venice, Italy, March 13-17, 1989.

M. Murakami, v. K. Pare et al., Second Stability Studies in the ATF Torsatron, ORNL/TM-11138, Oak Ridge National Laboratory, Martin Marietta Energy Systems, Inc., 1989.

G. V. Murphy, Robust LQRILTR Control System Design for a Low-Pressure Feedwater Heater Train with Time Delay, Ph.D. Dissertation, The University of Tennessee, Knoxville, 1990.

G. V. Murphy and J. M. Bailey, "LQG/LTR Robust Control System Design for a Low-Pressure Feedwater Heater Train," Proc. 1990 IEEE Southeastcon, Vol. 3, pp. 853-56 (April 1990).

P. J. Otaduy, C. R. Brittain, and L. A. Rovere, "Supervisory Control in a Distributed, Hicrarchical Architecture for a Multimodular LMR," Proc. IAEA IWGFR Specialists' Meeting Advanced Controls for Fast Reactors, pp. 2-210/2-219 (1989).

P. J. Otaduy, C. R. Brittain, and L. A. Rovere, "Supervisory, Hierarchical Control for a Multimodular ALMR," Proc. 7th Power Plunt Dynamics, Control and Testing Symp., pp. 2.01-2.12 (1989).

P. J. Otaduy and J. March-Leuba, LAPUR User's Guide, NUREG/CR-5421, ORNL/TM-11285, Oak Ridge National Laboratory, Martin Marietta Energy Systems, Inc., January 1990.

R. Paviotti-Corcuera, C. E. Ford, and R. B. Perez, Designing a Nuclear Data Base Prototype Using Oracle and Prolog, ORNL/TM-10984, Oak Ridge National Laboratory, Martin Marietta Energy Systems, Inc., November 1988.

R. Paviotti-Corcuera, C. E. Ford, A. W. Renshaw, S. J. Ball, and R. B. Perez, Designing an A-I Environmental Prototype for the Automatic Startup of EBR-II, ORNL/TM-11296, Oak Ridge National Laboratory, Martin Marietta Energy Systems, Inc., June 1990.

R. B. Perez, P. J. Otaduy, L. A. Rovere, and C. R. Brittain, "Lagrangian Forrnulation of Closedi-Loop Control Theory," Trans. Am. Nucl. Soc. 61, 160-62 (June 1990). 
R. B. Perez and R. T. Wood, "A Stochastic Method for Nuclear Power Plant Diagnosis," NATO Advanced Research Workshop on Noise and Nonlinear Phenomena in Nuclear Systems, Universidad Politecnia de Valencia, Spain, May 23-27, 1988.

A. L. Quells, R. E. Uhrig, and B. R. Upadhyaya, "Development of an Expert System for Signal Validation," Trans. Am. Nucl. Soc. 57, 237 (1988).

G. V. S. Raju and R. A. Kisner, "Fuzzy Logic Controller to a Steam Generator Feedwater Flow," Proc. American Control Conf. 2, pp. 1491-92 (1990).

G. V.S. Raju and R. A. Kisner, "Hierarchical Fuzzy Control," Internat. J. Control (in press).

D. A. Rasmussen, V. K. Pare et al., "The Role of Stellarators in Understanding Toroidal Transport Physics," 16th IEEE Internat. Conf. Plasma Science, Buffalo, N.Y., May 22-24, 1989.

M. J. Roberts, T. V. Blalock, and R. L. Shepard, "Tuned-Circuit Johnson Noise Thermometry," Proc. 7th Symp. Space Nuclear Power Systems, Albuquerque, N.M., January 10, 1990.

J. T. Robinson and R. A. Kisner, "An Intelligent Dynamic Simulation Environment: An Object-Oriented Approach," Proc. Third Internat. Symp. on Intelligent Control, pp. 687-92 (1988).

J. T. Robinson and P. J. Otaduy, "An Object-Oriented Simulation Package for Power Plants," Proc. 1988 Society for Computer Oriented Simulation Multiconf., pp. $55-58$ (1988).

S. Rosen, N. G" ussman, R. S. Booth, and W. J. Rowan, "The Status and DOE Vision for the National LMR Program," Trans. Am. Nucl. Soc. 61, 299-300 (June 1990).

L. A. Rovere, C. R. Brittain, and P. J. Otaduy, "Implementation of a Multimodular LMR Nuclear Plant Simulation on a Parallel Computer," Proc. 1989 Southeastern Simulation Conf., pp. 95-103 (1989).

L. A. Rovere, P. J. Otaduy, and C. R. Brittain, "Development of a Robust Model-Based Reactivity Control System," Proc. Third Internat. Conf. Simulation Methods in Nuclear Engineering. pp. 443-56 (1990).

L. A. Rovere, P. J. Otaduy, C. R. Brittain, and R. B. Perez, "Hierarchical Control of a Nuclear Reactor Using Uncertain Dynamics Techniques," Proc. 3rd IEEE Internat. Symp. Intelligent Control, pp. 713-18 (1988).

L. A. Rovere, P. J. Otaduy, and C. March-Leuba, "Development of an Uncertain Model Based Nonlinear Optimal Pressure Control System for a Nuclear Reactor," IEEE Nuclear Science Symposium, Orlando, Fla., November 9-11, 1988.

M. J. Saltmarsh, V. K. Pare et al., "Initial Experimental Results form the ATF Torsatron," 12th Int. Conf. on Plasma Physics and Controlled Nuclear Fusion Research, Nice, France, October 12-19, 1988.

R. L. Shepard, T. V. Blalock, L. C. Maxey, M. J. Roberts, and M. L. Simpson, "Optical Johnson Noise Thermometry," Proc. 2nd NASA Workshop on Non-Contact Temperature Measurement, Vol. 9-16, pp. $42-49$ (1989).

R. L. Shepard and A. Cezairliyan, "NASA NCTM Workshop." Proc. 2nd NASA Workshop on Non-Contact Temperature Measurement, Vol. 89-16, p. 299 (1989). 
R. L. Shepard, C. A. Hahs, J. A. Williams, and W. H. Ellis, Fabrication and Test of the High-Temperature, High-Sensitivity Fission Counter (HTHSFC-1), ORNL/ACP/LTR-89/3, Oak Ridge National Laboratory, Martin Marietta Energy Systems, Inc., August 1989.

R. L. Shepard and J. A. Williams, Recommended Design, Fabrication, and Testing of the High-Temperature, High-Sensitivity Fission Counter (HTHSFC), ORNL/ACP/LTR-89/6, Oak Ridge National Laboratory, Martin Marietta Energy Systems, Inc., August 1989.

C. M. Smith and R. C. Gonzalez, "Automated Long-Term Surveillance of a Commercial Nuclear Power Plant," IEEE Trans. Nucl. Sci. 35, 966-81 (February 1988).

O. L. Smith, A Fast Dynamic Analysis Methodology for Development and Operation of Controls for the Heavy Water Production Reactor, ORNL/NPR-90/25, Oak Ridge National Laboratory, Martin Marietta Energy Systems, Inc., September 1990.

O. L. Smith, Computer-Assisted Flexible Routing to Increase Usage and Cost Effectiveness of Urban and Suburban Mass-Transit Bus Systems, ORNL/TM-11361, Oak Ridge National Laboratory, Martin Marictta Energy Systems, Inc., January 1990.

O. L. Smith, Computer-Assisted Planning for Low-Intensity Conflict at Strategic National Facilities, ORNL/TM-11362, Oak Ridge National Laboratory, Martin Marietta Energy Systems, Inc., December 1989.

O. L. Smith, Methodology for Coupling the Air and Ground Modules in the State-of-the-Art Contingency Analysis Code, ORNL/TM-10785, Oak Ridge National I aboratory, Martin Marietta Energy Systems, Inc., December 1988.

O. L. Smith, ORGAME - A Fast Interactive Model for Contingency Analysis, ORNL/DSRD/TM-46, Oak Ridge National Laboratory, Martin Marietta Energy Systems, Inc., December 1989.

C. E. Snyder, N. E. Clapp, Jr., D. E. Smith, M. Terranova, J. Davis, J. L. Finney, P. G. Guthrie, G. B. Payne, and S. Webster, "Teamwork and Data Deliverables: A Map to Software and Training Design Integration," Proc. 11th InterservicelIndustry Training Systems Conf.. pp. 465-70 (1989).

J. A. Thie, B. Damiano, and L. R. Campbell, "Inference of Physical Phenomena from FFTF Noise Analysis," Proc. 7th Power Plant Dynamics, Control and Testing Symp., Vol. 2, p. 54-01, 1989.

L. H. Tsoukalas, R. C. Berkan, B. R. Upadhyaya and R. E. Uhrig, "Expert System Driven Fuzzy Control Application to Power Reactors," Pros. 2nd Internat. Conf. Tools for Artifical Intelligence, Washington, D.C., November 6-9, 1990.

R. E. Uhrig, "Use of Artificial Intelligence in Nuclear Power Plants," Proc. ANS Annual Meeting, Advances in Human Factors Research on Man/Computer Interactions: Nuclear and Bey'ond, pp. $210-15$ (1990).

R. E. Uhrig, "Neural Networks and Their Potential Application in Nuclear Power Plants," Proc. EPRI Conf. Expert Systems Applications in Nuclear Power Plants, Hemisphere Publishing Co., Vol. 1, pp. 1435-45 (1990). 
R. E. Uhrig, "Use of Neural Networks in the Operation of Nuclear Power Plants," Proc. Am. Assoc. Artificial Intelligence, Dayton, Ohio, October 29-31, 1990.

R. E. Uhrig, "Research in Artificial Intelligence for Nuclear Facilities," Trans. Am. Nucl. Soc. 61, 120-21 (June 1990).

R. E. Uhrig, "Use of Neural Networks in Nuclear Power Plant Diagnostics," Proc. Internat. Conf. Availability Improvements in Nuclear Power Plants, Madrid, pp. 1-19 (April 1990).

R. E. Uhrig, "Expert Systems and Their Use in Nuclear Power Plants," Advances in Nuclear Science and Technology, ed. Jeffery Lewis and Martin Becker, Plenum Publishing Corp., 1989, pp. 121-67.

R. E. Uhrig, "Opportunities for Automation and Control of the Next Generation of Nuclear Power Plants," Nucl. Technol. 88, 157-65 (November 1989).

R. E. Uhrig, "Use of Expert Systems in Nuclear Power Plants," Joint Korea-United States Seminar on Expert Systems for Electric Power Systems and Industries, Seoul, Korea, August 13-18, 1989.

R. E. Uhrig and R. J. Carter, Program Plan for Regulatory Research on Expert Systems, ORNL/NRC/LTR-89/5, Oak Ridge National Laboratory, Martin Marietta Energy Systems, Inc., March 1989.

R. E. Uhrig and R. J. Carter, Survey of Canadian Uses of Digital Computers in Control, Safety Systems, and Human-Machine Interfaces in Nuclear Power Plants, ORNL/NRC/LTR-89/6, Oak Ridge National Laboratory, Martin Marietta Energy Systems, Inc., 1989.

R. E. Uhrig and Zhichao Guo, "Use of Neural Networks to Identify Transient Operating Conditions in Nuclear Power Plants," Proc. Soc. Photo-Optical Instrum. Engineers, Symposia on Aerospace Sensing, Artificial Intelligence VII, Orlando, Florida, March 30, 1989.

R. E. Uhrig and L. F. Miller, "Use of Neural Networks for In-Core Fuel Management," Trans. Am. Nucl. Soc. 59, 59 (1989).

J. D. White, "Approach to Plant Automation with Evolving Technology," Proc. 7th Power Plant Dynamics, Control, and Testing Symp. 1, pp. 38.01-38.22 (1989).

J. D. White, "Research and Development on the Advanced Control Technologies to Nuclear Reactor Systems: the U.S. National Perspective," IAEA Technical Committee/Workshop on the Impact of Advanced Technologies on Reactor Systems, Vienna, November 6-9, 1989.

J. D. White, U.S. Department of Energy, Nuclear Energy, Program for Advanced Reactors Program Plan: FY 1988-1992," ORNL/M-642, Oak Ridge National Laboratory, Martin Marietta Energy Systems, Inc., 1988.

J. D. White, J. I. Sackett, L. R. Monson, and R. W. Lindsay, "Overview of the U.S. Program of Controls for Advanced Reactors," Proc. Specialists Meeting on Advanced Control for Fast Reactors, pp. 2.42-2.72 (1989). 
J. A. Williams, J. T. Mihalczo, C. W. Ricker, F. L. Glesius, and T. A. Kniss, "A High-Sensitivity, Position-Sensitive Fission Chamber for Subcriticality Measurement of Speni Fuel," Proc. 7th Symp. Radiation Measurements and Applications, p. 2E24, (1990); also Nucl. Instrum. Methods (December 1990).

T. L. Wilson, Jr., Feedwater Control System Status Report, ORNL/ACP/LTR-89/1, Oak Ridge National Laboratory, Martin Marietta Energy Systems, Inc., April 1989.

T. L. Wilson, Jr., and W. K. Wagner, "Multivariable Control for the PRISM ALMR," Proc. 7th Power Plant Dynamics, Control, and Testing Symp. 2, pp. 74.01-74.14 (1989).

R. T. Wood and T. L. Wilson, Jr., "Inherent Reactor Power Controller for a Metal-Fueled ALMR," IEEE Trans. Nucl. Sci. 37(2), 1032-39 (April 1990).

R. T. Wood and T. L. Wilson, Jr., Investigation of Reactivity Feedback Effects and Design of an Inherent Reactor Power Controller for a Metal-Fueled Advanced Liquid Metal Reactor, ORNL/ACP/LTR-88/1, Oak Ridge National Laboratory, Martin Marietta Energy Systems, Inc., October 1988.

\subsection{Research Instruments}

G. T. Alley and M. L. Bauer, "Data Processing and Display Algorithms for Portable Instruments," IEEE Trans. Nucl. Sci. 35(1), 559-61 (February 1988).

G. T. Alley, W. L. Bryan, M. S. Emery, J. E. Phelps, and S. R. Maddox, "Modular Survey Instrument System-MOSIS," $R \& D$ Magazine (1988).

G. A. Armstrong, M. L. Simpson, and D. W. Bouldin, "Design and Implementation of Moment Invariants for Pattem Recognition to VLSI," Proc. Tech. Symp. Optical Engineering and Photonics in Aerospace, pp. 222-28 (1990).

G. A. Armstrong, M. L. Simpson, and D. W. Bouldin, "VLSI Implementation of Moment Invariants for Automated Inspection," Proc. IEEE 22nd Southeastern Symp. System Theory, IEEE Computer Society Press, pp. 500-505 (1990).

M. L. Bauer, "Some Solutions to the On-Line Radiological Monitoring of Difficult Streams," IEEE Truns. Nucl. Sci. 35(1), $571-74$ (February 1988).

C. L. Bı itton, "Collider and Fixed-Target Electronics Development at Oak Ridge National Laboratory," Workshop on Major SSC Detectors, Tucson, Ariz., February 19-23, 1990.

C. L. Britton, Jr., F. T. Alley, W. L. Bryan, M. S. Emery, M. N. Ericson, D. W. Bouldin, and D. F. Newport, "Tool Integration and Enhancement for Ease of Standard Cell Circuit Development," IEEE Nucl. Sci. Symp., San Francisco, January 1990.

C. L. Britton, Jr., G. T. Alley, W. L. Bryan, M. S. Emery, M. N. Ericson, D. W. Bouldin, and D. F. Newport, "Tool Integration and Enhancement for Standard Cell Designs," Proc. 1989 VLSI Education Conf. \& Exposition, pp. 97-104 (1989). 
C. L. Britton, Jr., E. J. Kennedy, and W. M. Bugg, "VTC Preamplifier Development and Testing," Silicon Electromagnetic Calorimetry Collaboration, The University of Tennessee, Knoxville, June 9-10, 1990.

C. L. Britton, Jr., E. J. Kennedy, R. A. Todd, A. L. Y intenberg, M. L. Bauer, and W. M. Bugg, "Silicon Calorimetry Preampliníei Development and Testing," Snowmass Electronics Meeting, 'snowmass, Colo., June 29, 1990.

C. L. Britton, Jr., J. M. Rochelle, G. T. Alley, D. F. Newport, W. L. Bryan, and M. N. Ericson, "Chat acteristics of CMOS Analog Integrated Structures Using MOSIS," IEEE Nucl. Sci. Symp., San Francisco, January 1990.

C. L. Britton, Jr., R. A. Todd, E. J. Kennedy, and W. Mi. Bugg, "Bipolar Monolithic Preamplifiers for SSC Silicon Calorimetry," Symposium on Detector Research and Development for the Superconducting Super Collider, Fort Worth, Tex., October 15-18, 1990.

C. L. Britton, Jr., and A. L. Wintenberg, "Shaping, Sampling, and Buffering," Silicon Electromagnetic Calorimetry Collaboration, The University of Tennessee, Knoxville, June 9-10, 1990 ,

W. L. Bryan, S. R. Maddox, M. N. Ericson, C. L. Britton, M. S. Emery and G. T. Alley, "Advantages of a Modular Design Approach for Radiological Instrumentation," IEEE Trans. iNucl. Sci. 37(2), 873-77 (April 1990).

M. M. Chiles, "Lual Silicon Surface Barrier Detectors and Associated Electronics to Monitor Chemical Separation of ${ }^{249} \mathrm{Cf}$ and ${ }^{249} \mathrm{Bk}$," 7 th Symp. Radiation Measurements and Applications, Ann Arbor, Mich., May 21-24, 1990, Nucl. Instrum. Methods Phys. Res. A299, pp. 597-99 (1990).

M. M. Chiles, M. L. Bauer, and S. A. McElhaney, "Multienergy Neutron Detector for Counting Thermal Neutrons, High-Energy Neutrons, and Gamma Photons Separately," IEEE Trans. Nucl. Sci. 37(3), 1348-50 (June 1990).

M. M. Chiles and S. A. McElhaney, "Multi-Energy Neutron Detector for Counting Thermal Neutrons, High-Energy Neutrons, and Gamma Photons Separately," Health Physics Society 34th Annual Meeting, Albuquerque, N. M., June 27, 1989.

R. I. Crutcher, M. E. Buchanan, and R. W. Jones, Electromagnetic Pulse (EMP) Survey of the Louisiana State Emergency Operating Center, Baton, Rouge, Louisiana, ORNL/FEMA-89/2, Oak Ridge National Laboratory, Martin Marietta Energy Systems, Inc., September 1989.

J. C. Culioli, V. Protopopescu, C. L. Britton, Jr., and M. N. Ericson, "A Neural Network for Explicitly Ecunded Linear Programming," Proc. Internat. Joint Conf. Neural Networks 1, pp. 381-84 (1990).

J. C. Culioli, V. Protopopescu, C. L. Britton, Jr., and M. N. Ericson, "Neural Network Models for Linear Programming," Proc. Internat. Joint Conf. Neural Networks 1, pp. 293-96 (1990).

M. S. Emery, M.S. Blair, and J. E. Nyquist, "On-Site Method for Acquisition and Analysis of Sensor Data," Sensors Expo 90, Chicago, Sept. 11-13, 1990,

M. N. Ericson, C. L. Britton, Jr., and D. W. Bouldin, "A Virtual Zero-Time, Monolithic Systolic Sorting Array," Proc. IEEE Southeastcon '90, pp. 549-52 (1990). 
D. D. Falter, G. T. Alley, K. G. Falter, J. M. Rochelle, K. H. Valentine, R. D. Westbrook, G. E. Jellison, Jr., and P. H. Fleming, "Development of a Solar-Powered Infrared Injection Laser Microminiature Transmitting System," Proc. LASERS 1989, pp. 1081-87 (1989).

E. J. Kennedy, G. T. Alley, C. L. Britton, Jr., P. L. Skubic, B. Gray, and A. Wu, "Radiation Effects on JFETs, Mosfets and Bipolar Transistors, as Related to SSC Circuit Design," Symposium on Detector Research and Development for the Superconducting Super Collider, Fort Worth, Tex., October 15-18, 1990.

E. J. Kennedy and R. I. Vandermolen, "ORNL Irradiation Test of Components and Subsystems,

" France/USDOE Coordinators Meeting, Oak Ridge, Tenn., September 27-30, 1988.

R. J. Lauf, R. F. Wood, P. H. Fleming, and M. L. Bauer, New Applications of Silicon Micromachining, ORNL/TM-10590, Oak Ridge National Laboratory, Martin Marietta Energy Systems, Inc., 1988.

L. C. Maxey and T. V. Blalock, "Optimizing the Temperature Compensation of an Electronic Pressure Measurement System," ORNL/TM-11262, Oak Ridge National Laboratory, Martin Marietta Energy Systems, Inc., August 1990.

S. A. McElhaney, M. L. Bauer, M. M. Chiles, M. B. Emmett, and J. H. Todd, "Monte Carlo and Experimental Evaluation of BC-454 for use as a Multienergy Neutron Detector," IEEE Trans. Nucl. Sci. 37(3), 1351-58 (June 1990).

S. A. McElhaney, M. M. Chiles, and M. L. Bauer, "Thin Film Techniques for Developing a More Rugged Alpha Scintillation Detector," Proc. Health Physics Society 22nd Mid-Year Topical Meeting on Instrumentation, pp. 61-66 (December 1988).

S. A. McElhaney, M. M. Chiles, R. L. Lauf, and M. L. Bauer, "Ruggedized Alpha Radiation Detector," IEEE Trans. Nucl. Sci. 36(1), 1172-75 (Fcb. 1989).

S. A. McElhaney, M. M. Chiles, and J. A. Ramsey, "An Alpha/Beta/Gamma Health Physics Instrument with Pulse-Shape Discrimination," IEEE Tr-ns. Nucl. Sci. 1, 425-28, 1990.

S. A. McElhaney, J. A. Ramsey, M. L. Bauer, and M. M. Chiles, "A More Rugged Zns(Ag) Alpha Scintillation Detector," IEEE Trans. Nucl. Sci. 37(2), 868-72 (April 1990).

S. A. McElhaney, J. A. Ramsey, M. L. Bauer, and M. M. Chiles, "A Ruggedized $\mathrm{ZnS}(\mathrm{Ag}) /$ Epoxy Alpha Scintillation Detector," 7th Symposium on Radiation Measurements and Applications, Ann Arbor, Mich., May 21-24, 1990.

S. A. McElhaney, J. A. Ramsey, M. I. Bauer, and M. M. Chiles, "A Ruggedized $\mathrm{ZnS}(\mathrm{Ag}) / \mathrm{E}\urcorner \mathrm{xy}$ Alpha Scintillation Detector," Nuci. Instrum. Methods Phys. Res. A299, 111-14, 1990.

S. A. McElhaney and R. I. Vandermolen, Two-Dimensional Position-Sensitive Detectors for Small-Angle Neutron Scattering, ORNL/TM-11557, Oak Ridge National Laboratory, Martin Marietta Energy Systems, Inc., May 1990.

J. T. Mihalczo, N. W. Hill, E. D. Blakeman, and V. K. Pare, "Detection System Characteristics Using ${ }^{252}$ CF Ionization Chambers," 7th Symposium on Radiation Measurements and

Applications, University of Michigan, Ann Arbor, May 21-24, 1990. 
D. F. Newport, C. L. Britton, Jr., G. T. Alley, W. L. Bryan, M. S. Emery, M. N. Ericson, H. R. Brashear, and D. W. Bouldin, "Integrating and Enhancing Tools for ASIC Design Using MOSIS Fabrication," IEEE Trans. Nucl. Sci. 37(2), 370-73 (April 1990).

F. R. Ruppel, C. L. Carnal, and R. F. Lind, "Tuning Control Loops: An Empirical Approach," Control, pp. 40-45 (1990).

R. L. Shepard, T. V. Blalock, L. C. Maxey, M. J. Roberts, and M. L. Simpson, "Optical Johnson Noise Thermometry," Proc. NASA Workshop on Non-Contact Temperature Measurement, Vol. 89-16, pp. $42-49$ (June 1, 1989).

M. L. Simpson, L. C. Maxey, J. D. Muhs, M. Azar, H. Powell, and C. Ventrice, "Single Port, Two Color Particle Sensing System for Characterizing Wet Steam," Proc. Sensors Expo 90, Chicago, September 11-13, 1990, pp. 107C-2/107C-9.

S. F. Smith, K. N. Castleberry, and C. H. Nowlin, "Machine Monitoring via Motor-Current Demodulation Techniques," Proc. 44th Meeting Mechanical Failures Prevention Group, pp. 87-96 (1990).

C. E. Snyder, N. E. Clapp, Jr., D. E. Smith, M. Terranova, J. Davis, J. L. Finney, P. G. Guthrie, G. B. Payne, and S. Webster, "Teamwork and Data Deliverables: A Map to Software and Training Design Integration," Proc. 11th Interservice/Industry Training Systems Conf., pp. 465-70 (1989).

R. A. Todd, "Preamplifier Designs for Silicon Calorimetry Using Harris Semiconductor Bipolar VHFP Process," presented to Silicon Electromagnetic Calorimetry Collaboration, The University of Tennessee, Knoxville, June 9-10, 1990.

R. A. Todd, "System Noise Issues," presented to Silicon Electromagnetic Calorimetry Collaboration, The University of Tennessee, Knoxville, June 9-10, 1990.

R. A. Todd, L. C. Maxey, and M. M. Chiles, "Pulse Shape Discrimination Circuitry for Multienergy Neutron Detector," Proc. 34th Annual Meeting Health Physics Society, Vol. 56, Supplement 1, p. S37 (1989).

A. L. Wintenberg, C. L. Britton, Jr., M. L. Bauer, E. J. Kennedy, and R. A. Todd, "Considerations on the Design of Front End Electronics for SSC Silicon Calorimetry," Symposium on Detector Research and Development for the Superconducting Super Collider, Fort Worth, Tex., October 15-18, 1990,

\subsection{Measurement and Controls Engineering}

G. O. Allgood and L. C. Williams, "Basic Constructs for a Weapons Platform/Weapons Suite Mapping Onto Mission Profiles - A Classifier for JTLS ATO Expert System," Office of Joint Chiefs of Staff Military Aides Planning Conference, Hurlburt Field, Ft. Walton Beach, Fla., November 16, 1988.

W. H. Andrews, Jr., Security Implications of Personal Computer Connectivity, ORNL/TM-10978, Oak Ridge National Laboratory, Martin Marietta Energy Systems, Inc., November 1988. 
W. H. Andrews, Jr., M. F. Theofanos, C. D. Martin, and C. L. Carnal, Wang Alliance System Security Evaluation: Final Report, ORNL/TM-10795, Oak Ridge National Laboratory, Martin Marictta Energy Systems, Inc., May 1988.

J. D. Blanton, M. H. Cooper, A. J. Millet, and R. A. Vines, Instrument Calibration Plan of the Maintenance Management Department, ORNL/TM-10990, Oak Ridge National Laboratory, Martin Marietta Energy Systems, Inc., October 1990.

E. R. Broadaway, N. Fortson, L. D. Monteen, J. P. Stovall, and G. R. Wetherington, "Experiences with the Equipment," Chapter 8, Automating Electric Utility Distribution Systems: The Athens Automation and Control Experiment, Prentice-Hall, Inc., 1990, pp. 217-26.

E. R. Broadaway, J. B. Patton, J. S. Lawler, D. T. Rizy, and G. R. Wetherington, "Automation Software," Chapter 8, Automating Electric Utility Distribution Systems: The Athens Automation and Control Experiment, Prentice-Hall, Inc., 1990, pp. 187-216.

E. R. Broadaway, A. G. Roberts, and L. C. Williams, "An Easily Maintained Knowledge-Based System for Interactive Delivery of Detailed Technical Information," Proc. Conf. Artificial Intelligence, pp. 3-63-3-69, May 1990.

E. R. Broadaway, L. C. Williams, J. A. Mullens, W. L. Zabriskie, and A. G. Roberts, "Troubleshooting Complex Systems -- An Expert System, Interactive Video, Transportable PC Solution," Society for Applied Learning Technology, 5th Annual Conference on Applications of Artificial Intelligence and CD-ROM in Education \& Training, Arlington, Va., August 23-25, 1989.

P. L. Butler, J. D. Allen, and D. W. Bouldin, "Design and Implementation of a Parallel Computer for Expert System Applications," Proc. SPIE 1988 Technical Symp. Optics, Electro-Optics and Sensors, pp. 123-28 (1988).

P. L. Butler, J. D. Allen, and D. W. Bouldin, "Parallel Architecture for OPS5," Proc. 15th Annual Internat. Symp. Computer Architecture, pp. $452-57$ (1988).

C. L. Carnal, J. E. Hardy, and B. E. Lewis, "Simulation of a Continuous Rotary Dissolver," Summer Computer Simulation Conf., Austin, Tex., July 24, 1989.

C. L. Carnal and C. J. Remenyik, "Variable Time Delay in Dynamic System Simulation," Proc. Southeastern Simulation Conf., October 1989.

G. E. Courville, J. O. Hylton, W. P. Murray, A. V. Blalock, and C. J. Remenyik, "Electric Field Probes for Quantitative Moisture Measurments in Building Materials," Water Vapor Transmission Through Building Materials and Systems, American Society for Testing Materials (ASTM) Standard Technical Publication 1039, October 1989.

F. W. DePiero, W. W. Manges, R. L. Kress, M. R. Kedl, and W. R. Hamel, "Architecture for a Human-Robot Symbiotic System," Proc. IEEE 22nd Southeastern Symp. System Theory, pp. 78-83 (1990).

W. B. Dress, "Electronic Life and Synthetic Intelligent Systems," Computers Math. Applic. 20(4), 303-12 (1990).

W. B. Dress, "Artifical Neural Systems," Society for Computer Simulation, Nashville, Tenn., April 24, 1990. 
W. B. Dress, "Synthetic Organisms and Self-Designing Systems," Telematics and Informatics, 6(3\&4), 351-63 (1989).

W. B. Dress, "Genetic Optimization in Synthetic Systems," 1989 Neural Information Processing Systems Workshop on Neural Networks and Genetic Algorithms, Denver, Colo., December ?, 1989.

W. B. Dress, "Electronic Life Model," Seventh Internat. Conf. Mathematical and Computer Modeling, Chicago, August 3, 1989.

W. B. Dress, "Neural Networks as KBS Simulators," Society for Computer Simulation, Austin, Tex., July 28, 1989.

W. B. Dress, "Alternative Knowledge Acquisition: Developing a Pulse Coded Neural Network," J. Forth Application Res.5, 1-10 (May 1989).

W. B. Dress, "Neural Network Research at ORNL," Martin Marietta Laboratories, Baltimore, Md., February 15, 1989.

W. B. Dress, J. D. Allen, Jr., G. O. Allgood, and L. C. Williams, "Status Report," Proc. Martin Marietta First Workshop on Artificial Neural Systems, Baltimore, Md., February 15, 1989.

P. D. Ewing, "Approximation Technique for Determining Gain and Radiation Pattem of the Horn Antenna," Proc. Southeastcon 89 Conference and Exhibit 1, pp. 296-301 (1989).

P. D. Ewing, Gain and Electric Field Radiation Pattern Approximations for the E-Plane Horn Antenna, ORNL/TM-10983, Oak Ridge National Laboratory, Martin Marietta Energy Systems, Inc., December 1988.

J. E. Fowlkes, R. S. Kennedy, and G. O. Allgood, "Biomedical Evaluation and Systems Engineering for Simulators (BESS)," Proc. Internat. Training Equipment Conference and Exhibition (ITEC), Birmingham, England, April 9-11, 1990.

J. T. Glassell, Evaluation of the IBM Token Ring Network via the Proposed Standard Wiring Plan, ORNL/TM-1 1079, Oak Ridge National Laboratory, Martin Marietta Energy Systems, Inc., April 1989.

S. S. Gleason, M. A. Hunt, and W. B. Jatko, "Subpixel measurement of image features based on paraboloid surface fit," SPIE Internat. Symp. Applications in Optical Science and Engineering, Conference on Automated Inspection and High-Speed Vision Architectures IV, Boston, November 4-9, 1990.

J. M. Googe, R. A. Hess, P. D. Ewing, and D. C. Agouridis, Examination of Specifications and Standards Relating to the Susceptibility of Medical Electronic Devices to Transient Electrical Overstress, ORNL/TM-10769, Oak Ridge National Laboratory, Martin Marietta Energy Systems, Inc., May 1988. 
J. M. Googe, R. A. Hess, and M. R. Moore, Shielding Effectiveness of Indium-Tin-Oxide Composite Materials, NASC Report, January 1989.

J. H. Hannah, W. F. Johnson, and D. C. Watkin, Integral Fast Reactor Program Fuel Pin Processor Conceptual Design, ORNL/TM-10871, Oak Ridge National Laboratory, Martin Marietta Energy Systems, Inc., July 1988.

J. E. Hardy and J. E. Smith, "Mcasurement of Two-Phase Flow Momentum with Force Transducers," Intemat. Symp. on Two-Phase Flow, ASME Winter Annual Meetirig, Dallas, November 25-30, 1990.

B. S. Hoffheins, "Using Sensor Arrays and Pattem Recognition to Identify Organic Compounds," Westingthouse R\&D Interdepartmental Colloqium, October 5, 1989.

B. S. Hoffheins and R. J. Lauf, "Use of Chemical Sensor Arrays for Food and Fragrance Analysis," American Institue of Chemical Enginecrs 1988 Annual Meeting, Washington, D.C., ecember 1988.

B. S. Hoffheins, M. R. Moore, and M. L. Moore, "An Omnidirectional fintenna for a Personal RF Dosimeter," Proc. 1989 Internat. Symp. Hybrid Microelectronics, pp. $379-84$ (1989).

R. D. Horn, J. D. Birdwell, and G. O. Allgood, "Prediction of Helicopter Simulator Sickness," 29th Conf. Decision and Control, Honolulu, December 5-7, 1990.

K. W. Hylton and S. S. Gould, "Benefits Derived from Computer Integration of Complex Heat-Transfer Equipment," Proc. 36th Internat. Instrum. Symp., pp. 1973-79 (1990).

J. M. Jansen, Jr., Sonar Signal Analysis System, U.S. Navy Report, 1989.

W. B. Jatko, Application of a Human Visual Perception Paradigm for Automated Inspection of Monochromatic Security Documents, Ph.D Dissertation, The University of Tennessee, Knoxville, 1990.

W. B. Jatko, "A Survey of Camera Error Sources in Machine Vision Systems," Proc. Sensors Expo, Helmers Publishing Co., pp. 301C1-5 (1989).

W. B. Jatko, M. A. Hunt, and K. W. Tobin, "Nonlinear Filter Derived From Topological Image Features," SPIE 1990 Symp. Remote Sensing and Signal \& Image Processing, Orlando, Fla., April 16-20, 1990.

R. F. Lind and D. K. Mee, "Optical Pyrometer Temperature Measurement in Metal Casting Operations," Proc. Sensors Expo, Cleveland, Ohio, September 12-14, 1989; Helmers Publishing, Inc., pp. 301 A-1-301A-4, (1989), and Expocon Management Assoc.

W. W. Manges, G. O. Allgood, and D. H. Thompson. "Mapping a Hierarchical Control Strategy onto a Distributed System Architecture," Proc. 1988 Internat. Symp. Communications and Controls, Baton Rouge, La., October 19-21, 1988, pp. 1152-60 (1988).

W. W. Manges, W. R. Hamel, C. R. Weisbin, J. R. Einstein, B. L. Burks, D. H. Thompson, R. R. Feezell, and S. M. Killough, "Development of the Hermies III Mobile Robot Research Testbed at Oak Ridge National Laboratory," Proc. ANS Meeting on Robotics and Remote Systems, Charleston, S.C., March 13-16, 1989, pp 2.3.1-2.3.9 (1989). 
J. A. McEvers, T. L. Bowers, and N. Edwards, Air Pollution Effects Field Research Facility: 1. Ozone Flow' Control and Monitoring System, ORNL/TM-10758, Oak Ridge National Laboratory, Martin Marietta Energy Systems, Inc., January 1989.

J. A. McEvers and F. D. Boercker, A Post-Installation Validation of the Energy Monitoring and Control System at Ft. Lee, Virginia, ORNL/TM-10647, Oak Ridge National Laboratory, Martin Marietta Energy Systems, Inc., February 1989.

G. N. Miller, Project Manager, Air Cal/Verification Processing Report Technical Report, ORNL/Sub/85-CN946C\&89/10/02, Oak Ridge National Laboratory, Martin Marietta Energy Systems, Inc., March 1990.

G. N. Miller, Project Manager, AMFIP Phase II Telemetry System Design Subtrack 1206.12 Bandwidth Analysis Technical Memorandum, ORNL/Sub/85-CN946C\&89/7/01, Oak Ridge National Laboratory, Martin Marietta Energy Systems, Inc., December 1989.

G. N. Miller, Project Manager, AMFIP Phase II Top Level System Description, ORNL/Sub/85-CN946C/02\&89-3, Oak Ridge National Laboratory, Martin Marietta Energy Systems, Inc., June 1990.

G. N. Miller, Project Manager, AMFIP Phase II Top Level Systems Design Subtask 1103.31-.34 Draft Technical Report, ORNL/Sub/85-CN946C\&89/3/01, Oak Ridge National Laboratory, Martin Marietta Energy Systems, Inc., February 1990.

G. N. Miller, Project Manager, AMFIP Test Module Beamforming Procedures Technical Memorandum, ORNL/Sub/85-CN946C\&89/4/01, Oak Ridge National Laboratory, Martin Marietta Energy Systems, Inc., July 1990.

G. N. Miller, Project Manager, AMFIP Test Module Processing System (ATMPS) Sound Pressure Level (SPL) Processing Technical Memorandum, ORNL/Sub/85-CN946C\&89/4/02, Oak Ridge National Lahoratory, Martin Marietta Energy Systems, Inc., July 1990.

G. N. Miller, Project Manager, AMFIP Test Module Processing System (ATMPS) Source Power Level (SPL) Processing Version 2.0 Technical Memorandum, ORNL/Sub/85-CN946C\&89/4/04, Oak Ridge National Laboratory, Martin Marietta Energy Systems, Inc., March 1990.

G. N. Miller, Project Manager, AMFIP Test Module Tracking Procedures Technical Memorandum, ORNL/Sub/85-CN946C\&89/4/03, Oak Ridge National Laboratory, Martin Marietta Energy Systems, Inc., July 1990.

G. N. Miller, Project Manager, AMFIP User's Meeting, DTRC, 4 June 1990, Technical Memorandum, ORNL/Sub/85-CN946C\&90/2/01, Oak Ridge National Laboratory, Martin Marietta Energy Systems, Inc., June 1990.

G. N. Miller, Project Manager, ATMPS Utilities Technical Memorandum, ORNL/Sub/85-CN946C\&89/4/05, Oak Ridge National Laboratory, Martin Marietta Energy Systems, Inc., April 1990.

G. N. Miller, Project Manager, Array Evaluation Test Quick-Look Processing Report Technical Memorandum, ORNL/Sub/85-CN946C\&05/89/10, Oak Ridge National l_aboratory, Martin Marietta Energy Systems, Inc., July 1990. 
G. N. Miller, Project Manager, Array Evaluation Quick-Look Processing Test Plan Technical Memorandum, ORNL/Sub/85-CN946C\&89/10/03, Oak Ridge National Laboratory, Martin Marietta Energy Systems, Inc., May 1990.

G. N. Miller, Project Manager, Cooper Versus Optical Fiber for the High Gain Array Subtrack 1206.11 Cooper vs Fiber Optics Technical Report, ORNL/Sub/85-CN946C\&89/7/02, Oak Ridge National Laboratory, Martin Marietta Energy Systems, Inc., January 1990.

G. N. Miller, Project Manager, Data Acquisition and Screening Technical Memorandum, ORNL/Sub/85-CN946C\&89/4/08, Oak Ridge National Laboratory, Martin Marietta Energy Systems, Inc., April 1990.

G. N. Miller, Project Manager, Delta-Sigma Analog-to-Digital Converter Evaluation Technical Memorandum, ORNL/Sub/85-CN946C\&90/4/03, Oak Ridge National Laboratory, Martin Marietta Energy Systems, Inc., July 1990.

G. N. Miller, Project Manager, Fiber Optic Rotary Joints Technical Memorandum, ORNL/Sub/85-CN946C\&90/4/02, Oak Ridge National Laboratory, Martin Marietta Energy Systems, Inc., July 1990.

G. N. Miller, Project Manager, Gain Analysis Technical Memorandum, ORNL/Sub/85-CN946C\&89/4/06, Oak Ridge National Laboratory, Martin Marietta Energy Systems, Inc., April 1990.

G. N. Miller, Project Manager, High Gain Array Telemetry Handbook Volume 1: Preliminary Circuit Architectures Technical Memorandum, ORNL/Sub/85-CN946C\&89/7/03, Oak Ridge National Laboratory, Martin Marietta Energy Systems, Inc., June 1990.

G. N. Miller, Project Manager, High Gain Array Telemetry Handbook Volume 2: Preliminary Power and Volume Analysis Technical Memorandum, ORNL/Sub/85-CN946C\&89/104, Oak Ridge National Laboratory, Martin Marietta Energy Systems, Inc., June 1990.

G. N. Miller, Project Manager, In-Depth Processing Test Plan, ORNL/Sub/85-CN946C\&89/10/06, Oak Ridge National Laboratory, Martin Marietta Energy Systems,

G. N. Miller, Project Manager, Imaging/Source Analysis Technical Memorandum, ORNL/Sub/85-CN946C\&89/4/07, Oak Ridge National Laboratory, Martin Marietta Energy Systems, Inc., August 1990.Inc., April 1990.

G. N. Miller, Project Manager, Minutes of the User Requirements Meeting 9/7/90 Technical Memorandum, ORNL/Sub/85-CN946C\&90/2/03, Oak Ridge National Laboratory, Martin Marietta Energy Systems, Inc., September 1990.

G. N. Miller, Project Manager, Multimode Optical Fiber Bandwidth Relationship to Bit-Error-Rate Technical Memorandum, ORNL/Sub/85-CN946C\&90/4/04, Oak Ridge National Laboratory, Martin Marictta Energy Systems, Inc., July 1990.

G. N. Miller, Project Manager, Multimode Optical Fiber Versus Singlemode Optical Fiber in Ocean Systems Technical Memorandum, ORNL/Sub/85-CN946C\&90/4/01, Oak Ridge National Laboratory, Martin Marictta Energy Systems, Inc., June 1990. 
G. N. Miller, Project Manager, Submarine Feasibility Quick-Look Processing Test Plan Tecinical Memorandum, ORNL/Sub/85-CN946C\&89/10/04, Oak Ridge National Laboratory, Martin Marietta Energy Systems, Inc., June 1990.

G. N. Miller, WBS Sublevel Structure for AMFIP Phase II, ORNL/Sub/85-CN946C\&89/5/01, Oak Ridge National Laboratory, Martin Marietta Energy Systems, Inc., July 1990.

J. A. Mullens, L. C. Williams, and W. L. Zabriskie, "An Integrated Diagnostic System for a Process Controller," Proc. Ist Internat. Machinery Monitoring and Diagnostic Conf., pp. 45-49, Library of Congress Cat. No 89-51139 (September 1989).

D. T. Rizy, E. R. Broadaway, J. S. Lawler, J. H. Reed, and G. R. Wetherington, "Monitoring and Control," Chapter 3, Automating Electric Utility Distribution Systems: The Athens Automation and Control Experiment, Prentice-Hall, Inc., 1990, pp. 41-50.

A. G. Roberts, E. R. Broadaway, and J. A. Jefferis, "Implementation of an Interactive, Knowledge-Based Assistant for Diagnosis and Repair of Complex Control Systems," Proc. 4th Annual Expert System Conf., pp. 149-56 (April 1990).

R. W. Rochelle, M. R. Moore, R. S. Thomas, P. D. Ewing, R. A. Hess, and B. S. Hoffheins, $A$ Personal Radio-Frequency Dosimeter with Cumulative-Dose Recording Capabilities, ORNL/TM-11422, Oak Ridge National Laboratory, Martin Marietta Energy Systems, Inc., January 1990.

R. W. Rochelle, M. R. Moore, R. S. Thomas, P. D. Ewing, R. A. Hess, and B. S. Hoffheins, "A Personal Radio-Frequency Dosimeter with Cumulative-Dose Recording Capabilities," Proc. Sensors Expo, pp. 107B1-9 (1990).

F. R. Ruppel, Development of a Smart Temperature Measurement System Based on a Self-Calibrating Thermocouple, ORNL/TM-11127, Oak Ridge National Laboratory, Martin Marictta Energy Systems, Inc., April 1989.

F. R. Ruppel, C. L. Carnal, and R. F. Lind, "Tuning Control Loops: An Empirical Approach," Control (December 1990).

F. R. Ruppel, "Modeling A Sclf-Calibrating Thermocouple For Use in a Smart Temperature Measurement System," Proc. IEEE Instrumentation/Measurement Technology Conf., Cat. No. 90CH2735-9, pp. 94-99 (1990).

F. R. Ruppel, "Using Self-Calibrating Thermocouples in Industry," Proc. Sensors Expo, pp. 301B-1-5 (1989).

K. W. Tobin, M. A. Hunt, and W. B. Jatko, "High Resolution, Three-Dimensional Image Registration," Proc. SPIE 33rd Annual Internat. Tech. Symp. Optical \& Optoelectronic Applied Science \& Engineering, Applications of Digital Image Processing XII 1153, p. 541 (1989).

K. A. Wakefield and S. S. Gould, "Benefits Derived from Computer Integration of Complex Heat-Transfer Equipment," Proc. 36in Internat. Instrum. Symp., pp. 1973-79 (1990).

G. R. Wetherington, Jr., Project Manager, MAX System Interface Structure Charts and Procedure and Function Lists, ORNL/Sub/85-CN946C\&89/1/01, Oak Ridge National Laboratory, Martin Marietta Energy Systems, Inc., July 1989. 
G. R. Wetherington, Jr., Project Manager, XBT Climatology for XBT Quality Control Technical Memorandum, ORNL/Sub/85-CN946C\&89/11/01, Oak Ridge National Laboratory, Martin Marietta Energy Systems, Inc., October 1989.

G. R. Wetherington, Jr., Project Manager, XBT Climatology for XBT Quality Control Update Technical Memorandum, ORNL/Sub/85-CN946C\&89/11/03, Oak Ridge National Laboratory, Martin Marietta Energy Systems, Inc., April 1990.

G. R. Wetherington, Jr., Project Manager, XBT Distribution Tables for Exuma Sound Technical Memorandum. ORNL/Sub/85-CN946C\&89/11/02, Oak Ridge National Laboratory, Martin Marietta Energy Systems, Inc., March 1990.

B. R. Whitus, Bristol Babcock DPC 3330 Controller Evaluation, ORNL/TM-11114, Oak Ridge National Laboratory, Martin Marietta Energy Systems, Inc., April 1989.

L. C. Williams, "Implementation of an OPS5 Derivative on the NOVIX RISC Processor," J. Forth Applications Res. 1, 135-36 (1988).

L. C. Williams and E. R. Broadway, "Implementation of a Customizable Instruction Authoring and Delivery System," Proc. Soc. Applied Learning Technol. 5th Annual Conference on Application of Artificial Intelligence and CD-ROM in Education \& Training, pp. $35-36$ (1989).

\subsection{Maintenance Management Department}

J. D. Blanton, B. G. Eads, D. N. Keller, C. W. Kunselman, D. R. Miller, A. J. Millet, C. T. Stansberry, and P. J. Wilkerson, Instrumentation and Controls Division Maintenance Management Plan FY 1990-FY 1992, ORNL/TM-11537, Oak Ridge National Laboratory, Martin Marietta Energy Systems, Inc., June 1990.

D. N. Keller, Maintenance Management Department Annual Work Plan FY 1990-1992, ORNL/TM-11428, Oak Ridge National Laboratory, Martin Marietta Energy Systems, Inc., January 1990.

C. T. Stansberry, S. M. Odom, and C. D. Martin, Maintenance Information and Data Acquisition System (MIDAS), ORNL/TM-11287, Oak Ridge National Laboratory, Martin Marietta Energy Systems, Inc., September 1989.

\subsection{Miscellaneous}

B. G. Eads, "I\&C Signals Development Bulletin No. 7, Flow Vector Instrumentation System," 1988.

B. G. Eads, Instrumentation and Controls Division Progress Report for the Period July 1, 1986 to June 30, 1988, ORNL-6524, Oak Ridge National Laboratory, Martin Marietta Energy Systems, Inc., December 1988. 


\section{SCIENTIFIC AND \\ PROFESSIONAL ACTIVITIES, \\ ACHIEVEMENTS, AND AWARDS}

July 1, 1988 - June 30, 1990

D. C. Agouridis

Member, Institute of Electrical and Electronics Engineers

Member, Eta Kappa Nu

Member, Gamma Alpha

Listing in Who's Who in Technology

C. G. Allen

Senior Member, Instrument Society of America

Member, I\&C Safety Committee

Member, MMD MAJIC Committee

G. T. Alley

Member, Institute of Electrical and Electronics Engineers

Member, Eta Kappa Nu

Member, Tau Beta Pi

Registered Professional Engineer

Martin Marietta Energy Systems, Inc., Technical Achievement Award, 1990;

Co-Organizer, Short Course "Designing ASICs," presented at the 1989 Nuclear

Science Symposium, San Francisco, January 1990

G. O. Allgood

Senior Member, Institute of Electrical and Electronics Engineers

Senior Member, Instrument Society of America

Member, IEEE Control Systems Society

Member, Operations Research Society of America

Member, Eta Kappa Nu

Member, Tau Beta Pi

Listing in The International Who's Who in Engineering

Registered Professional Engineer

Invited Paper: "Basic Constructs for a Weapons Platform/Weapons Suite Mapping onto Mission Profiles - A Classifier For JTLS ATO Expert System," G. O. Allgood and L. C. Williams, Office of Joint Chiefs of Staff Military Aides Planning Conference, Hurlburt Field, Ft. Walton Beach, Florida, November 16, 1988 
A. H. Anderson, Jr.

Member. Institute of Electrical and Electronics Engineers

Member, Eta Kappa Nu

Member, Tau Beta Pi

Registered Professional Engineer

W. H. Andrews, Jr.

Senior Member, Instrument Society of America

Meinber, Computer Security Institute

Member, IEEE Computer Society

Member, Eta Kappa Nu

S. P. Baker

Senior Member, Instrument Society of America

Registered Professional Engineer

\section{S. J. Ball}

Member, Society for Computer Simulation

Member, Sigma Xi

Member, ORNL Reactor Operations Review Committee

D. D. Bates

Member, Martin Marietta Energy Systems Inventors' Forum

Member, Fusion Energy Division Committee on Major Electrical Equipment Review

Member, Fusion Energy Division Committee to Review LCTF Coil Protection System

Member, Fusion Energy Division Major Electrical Review Committee

Member, Fusion Energy Division Safety Review Committee for ISX-B Gyrotron Power System

R. E. Battle

Member, Institute of Electrical and Electronics Engineers; Newsletter Editor,

Oak Ridge Section

Registered Professional Engineer

Member, ANS/IEEE Working Group 7-4.3.2, Safety Criteria for the Application of

Programmable Digital Computers in Nuclear Power Plants

M. L. Bauer

Member, American Vacuum Society; Member, Executive Committee, Tennessee Valley Chapter Member, Society of Photo-Optical Instrumentation Engineers

U.S. Patent No. 4,924,450, UltraSonic Ranging and Data Telemetry System, May 8, 1990

A. V. Blalock

Member, Eta Kappa Nu

Member, Tau Beta Pi

Invited Paper: Water Vapor Transmission Through Building Materials and Systems,

G. E. Courville, J. O. Hylton, W. P. Murray, A. V. Blalock, and C. J. Remenyik,

"Electric Field Probes for Quantitative Moisture Measurements in Building

Materials," American Society for Testing Materials Standard Technical Publication

1039 


\section{T. V. Blalock}

Member, Institute of Electrical and Electronics Engineers

Haliburton Engineering Professorship. The University of Tennessee

\section{J. L. Blankenship}

Senior Member, Institute of Electrical and Electronics Engineers

Member, American Physical Society

\section{J. D. Blanton}

Senior Member, Instrument Society of America

Member, ORNL Health Physics Instrument Committee

\section{R. S. Booth}

Fellow, A merican Nuclear Society

\section{R. Brittain}

"Development of a Decomposition Technique for Nonlinear Feedback Control of Large-Scale Systems," C. R. Brittain, Dissertation presented for the Doctor of Philosophy Degree, The University of Tennessee, Knoxville, May 1990

Invited Paper: "Supervisory, Hierarchical Control for a Multimodular ALMR," P. J. Otaduy, C. R. Brittain, L. A. Rovere, 7th Power Plant Dynamics, Control, and Testing Symposium, Knoxville, Tennessee, May 15-17, 1989

Invited Paper: "Supervisory Control in a Distributed, Hierarchiral Architecture for a Multimodular LMR," P. J. Otaduy, C. R. Brittain, L. A. Rovere, IAEA/IWGFR Specialists' Meeting, Advanced Controls for Fast Reactors, Argonne, Ill., June 20-22, 1989

W. L. Bryan

Member, Institute of Electrical and Electronics Engineers

\section{E. Buchanan}

Member, ETA Kappa Nu

Member, Phi Kappa Phi

\section{L. Carnal}

Member, Institute of Electrical and Electronics Engineers

Faculty Advisor and Member, Eta Kappa Nu

Member, Phi Kappa Phi

Member, Tau Beta Pi

Registered Professional Engineer

Invited Paper: "Variable Time Delay in Dynamic System Simulation," C. L. Carnal and C. J. Remenyik, Proceedings of the Southeastem Simulation Conference, October 1989

\section{R. Cinnamon}

Member, National Institute for Certification in Engineering Technology

N. E. Clapp, Jr.

Senionr Member. Instrument Society of America 
Member, Phi Eta Sigma

Member, Phi Kappa Phi

Member. EPRI Instrument Calibration Reduction Program Advisory Committee

Member, ORNL Scientific and Technical Computing User Advisory Committee

D. A. Clayton

Member, Digital Equipment Corporation Users' Society

Member, Institute of Electrical and Electronics Engineers

Member, IEEE Automatic Controls Society

Member, IEEE Computer Society

Member, Eta Kappa Nu

R. I. Crutcher

Registered Professional Engineer

\section{B. Damiano}

Member, American Nuclear Society

Member, American Society of Mechanical Engineers

Member, Tau Beta Pi

Registered Professional Engineer

\section{J. B. Davidson}

Member, Sigma Xi

Invited Paper: "A Neutron-Sensitive Image Intensifier-Television System,"

J. B. Davidson, H. G. Smith, and R. A. Willems, Third World Conference on Neutron Radiography, Osaka, Japan, May 14-18, 1989

Invited Panelist: "Neutron Detectors," ORNL/BNL Workshop on Neutron Scattering Instrumentation at High Flux Reactors, Oak Ridge, Tenn., June 5-7, 1989

Invited Paper: "Instrumentation Development for Molecular Biology," U. S. DOE Human Genome Program, Contractor/Grantee Workshop, Santa Fe, N.M., November 3-4, 1989

Invited Paper: "TV-Based Neutron Detectors," DOE/DMS Discussion Meeting on Neutron Scattering, Gatlinburg, Tenn., May 14-16, 1990

K. W. Drescher

I\&C Electronic Design and Integrated Fabrication Committee

W. B. Dress

Member, American Association for the Advancement of Science

Member, American Association for Artificial Intelligence

Member, American Physical Society

Member, Association for Computing Machinery

Member, FORTH Interest Group

Member, International Neural Network Society

Member, Institute of Electrical and Electronics Engineers

Member, Classification Society of North America

Editor, Nuerocon-1 Conference Proceedings, Award of Merit, Society for Technical Communication, 1989

Adjunct Professor, The University of Tennessee, Knoxville 
Reviewer for Nuclear Technology

Reviewer for Journal of FORTH Application and Research

Member, ORNL Publication Award Review Committee

Proposal Reviewer for the National Science Foundation

Proposal Reviewer for U.S. Department of Energy SBIR Grants

ORNL Speaker's Bureau: "Electronic Life and Artifical Neural Systems," East Tennessec Section of the American Society of Mechnical Engineers Annual Meeting, September 13,1990

Guest Speaker: "Electronic Life and Artifical Neural Systems," Richmond Joint Engineers Council, Annual Meeting, February 22, 1990

Invited Paper: "Genetic Optimization in Synthetic Systems," 1989 Neural Information Processing Systems Workshop on Neural Networks and Genetic Algorithms, Denver, Decemher 1, 1989

Seminar: "Neural Networks and Synthetic Systems," and "Artificial Life," Oberlin College, Oberlin, Ohio, May 3, 1990

ORAU Traveling Lecture: "Electronic Life and Artifical Neural Systems," University of Louisv:"'e, February 16, 1990

Seminar: "Evolutionary Biocomputing," American University, Washington, D.C., April 20, 1990

Invited Paper: "Artifical Neural Systems," Society for Computer Simulation, Nishville, Tenn., April 24, 1990

Invited Paper: "Electronic Life Model," Seventh Intermational Conference on Mathematical and Computer Modeling, Chicago, August 3, 1989

Invited Paper: "Neural Networks as KBS Simulators," Society for Computer Simulation, Austin, Texas, July 28, 1989

Invited Speaker: "Artificial Neural Systems," UT Science Club, Knoxville, Tenn., February 12, 1989

Invited Paper: "Neural Network Research at ORNL," Martin Marietta Laboratories, Baltimore, February 15, 1989

Session Chairman, 1989 Goddard Conference on Space Application of Artificial Intelligence, May 16, 1989

\section{B. G. Eads}

Senior Member, Instrument Society of America

Member, Institute of Electrical and Electronics Engineers

Member, Tau Beta Pi

Member, AVID Advisory Committee

Member. Center for Global Environmental Studies

Advisory Committee, Center for Electric Power, Tennessee Technological University

\section{R. P. Effler}

Member, ORNL X-Ray Safety Standards Review Committee

Member, Instrument Society of America

Member, MENSA

\section{S. Emery}

Member, Institute of Electrical and Electronics Engineers

Invited Paper: "On-Site Method for Acquistion and Analysis of Sensor Data,"

M. S. Emery, M. S. Blair, and J. E. Nyquist, Sensors Expo, Chicago,

Septembe 11,1990 


\section{P. D. Ewing}

Member, Institute of Electrical and Electronics Engineers

Member, Eta Kappa Nu

Member, Kappa Mu Epsilon

Member, Advisory Board of Southeastern Consortium for Minorities in Engineering

K. G. Falter

Martin Marietta Energy Systems 1990 Technical Achievement Award, "Development of a Solar-Powered Micro-Miniature Transmitting System," May 5, 1990

\section{R. J. Fox}

Member, Institute of Electrical ar 4 Electronics Engineers

\section{E. B. Freer}

Member, Institute of Electrical and Electronics Engineers

Member, IEEE Computer Society

Member, IEEE Power Engineering Society

Member, Phi Kappa Fhi

Member, Tau Beta Pi

D. N. Fry

Member, American Nuclear Society

Member, Tau Beta Pi

\section{T. M. Gayle}

Member, Air Pollution Control Association

Member, American Chemical Society

Registered Professional Engineer

Invited Paper: "A Laboratory Scale Liquid/S lid Smoke Generator to Simulate the XM55 Field Systems," J. H. Moneyhun, T. M. Gayle, and R. A. Jenkins, Smoke/Obscurants Symposium XII, Kossiakoff Conference and Education Center, The Johns Hopkins University, Laurel, Md., April 19-21, 1988

Invited Paper: "Chemical and Toxicological Properties of the Combustion Products of Rifle and Gun Systems," R. A. Jenkins, J. H. Moneyhun, T. M. Gayle, and R. H. Ross, Pulmonary Research Review and Analysis Meeting, Fitzsimons Army Medical Center, Auroro, Colo., September 20-22, 1988

\section{F. R. Gibson}

Member, Instrument Society of America

\section{J. T. Glassell}

Member, Tau Beta Pi

\section{S. S. Gould}

Senior Member, Instrument Society of America Member, SME/CASA MAP/TOP Users Society

Honorary Member, Delta Kappa Omicron

Member, Fusion Energy Division Advisory Review Committee, IFSMTF Data System Upggrade Pâtí 
Member, Y-12 Plant Manufacturing Automation Committee

Chairman, Technical Paper Session, ISA 36th International Instrumentation Symposium, Denver, May 1990

C. A. Hahs

Member, ASME Operations, Applications, and Components Committee (Pressure Vessel and Piping Division, Valves)

Member, National Society of Professional Engineers

Member, Oak Ridge Mobile Steam Society

Member, Tennessee Society of Professional Engineers

Registered Professional Engineer, Missouri

\section{J. E. Hardy}

Member, American Society of Mechanical Engineers

Member, Instrument Society of America

Registered Professional Engineer

R. A. Hess

Member, IEEE Electromagnetic Compatibility Society

\section{J. S. Hicks}

Member, Institute of Electrical and Electronics Engineers

Member, Phi Kappa Phi

Member, Sigma Pi Sigma

\section{S. Hileman}

Member, Instrument Society of America

N. W. Hill

Member, Institute of Electrical and Electronics Engineers

Member, U.S. NIM-CAMAC Committee

Member, Review Committee, Nuclear Instruments and Methods, North Holland, Amsterdam

\section{B.S. Hoffheins}

M.S. Electrical Engineering, The University of Tennessee, Knoxville, August 1989

Invited Paper: "Use of Chemical Sensor Arrays for Food and Fragrance Analysis,"

B. S. Hoffheins and R. J. Lauf, American Institute of Chemical Engineers 1988

Annual

Meeting, Washington, D.C., December 1988

Invited Paper: "Using Sensor Arrays and Pattem Recognition to Identify Organic

Compounds," Westinghouse R\&D Interdepartmental Colloqium, October 5, 1989

\section{A. Hunt}

Member, Institute of Electrical and Electronics Engineers

Member, Society of Photo-Optical Instrumentation Engineers

\section{J. O. Hylton}

Member, Instrument Society of America

Member, Sigma Xi 
Invited Paper: G. E. Courville, J. O. Hylton, W. P. Murray, A. V. Blalock, and C. J. Remenyik, "Electric Field Probes for Quantitative Moistire Measurements in Building Materials," in Water Vapor Transmission T!'rough Building Materials and Systems, American Society for Testing Materials Standard Technical Publication 1039

\section{K. A. Hylton}

Member, Association for Computing Machinery

Member, Instrument Society of America

R. W. Ingle

Member, Eta Kappa Nu

Member, Tau Beta Pi

Member, Phi Kappa Phi

Registered Professional Engineer

Chairman, ORNL Stores Stock Advisory Committee

J. M. Jansen, Jr.

Member, Institute of Electrical and Electronics Engineers

Member, IEEE Computer Society

Member, IEEE Subcommittee on Real-Time Systems

Member, Kappa Mu Epsilon

Member, Phi Kappa Phi

Member, Sigma Pi Sigma

W. B. Jatko

Member, Golden Key Society

Member, Society of Motion Picture and Television Engineers

Member, Eta Kappa Nu

Member, Phi Eta Sigma

Member, Phi Kappa Phi

Member, Tau Beta Pi

\section{E. B. Johnson}

Fellow, American Nuclear Society; Member, Publications Steering Committee;

Member, ANS Standards Committee; Member and Secretary, Standards

Subcommittee 8, Fissionable Materials Outside Reactors; Member and Secretary,

Standard Consensus Committee N16, Nuclear Criticality Safety; Member, Standards

Subcommittee 1, Performance of Critical Experiments

Session Chairman, "Experience in the Use of Operational Controls for Nuclear Criticality

Safety," (all invited papers), 1988 ANS Winter Meeting

Member, Special Program Committee, ANS Nuclear Criticality Safety Division

Member, American Physical Society

Member, New York Academy of Sciences

Mernber, Sigma Xi

Administrative Judge, NRC Atomic Safety and Licensing Board Panel

Member, ORNL Reactor Operations Review Committee

Co-Op Coordinator, I\&C Divison 


\section{R. C. Juras}

Member, Institute of Electrical and Electronics Engineers

\section{E. J. Kennedy}

Member, Institute of Electrical and Electronics Engineers

Invited Paper: "ORNL Irradiation Test of Components and Subsystems," E. J. Kennedy and R. I. Vandermolen, France/USDOE Coordinators Meeting, Oak Ridge, Tenn., September 27-30, 1988

Invited Speech: "Electronics Irradiation Testing at ORNL," C. Britton, Jr., and E. J. Kennedy, IEEE Nucl. Sci. Symp. (Radiation Hardened Electronics for the SSC), November 10, 1988

Book: Operational Amplifier, Theory and Applications, Holt, Rinehart and Winston, New York, 1988

\section{R. A. Kisner}

Registered Professional Engineer

Member, Babcock \& Wilcox Owners Group Advanced Central System Task Force Advisory Panel

Member, ANS/IEEE working group for revising ANS-7-4.3.2/IEEE WG 6.4, "Application Criteria for Programmable Digital Computer Systems in Safety Systems of Nuclear Power Generating Stations"

Member, ORAU Traveling Lecture Program

Reviewer, IEEE Transactions on Nuclear Science

Invited Paper: "Automated Start-Up of EBR-II: A Preview," IAEA Specialist's Meeting on Advanced Controls for Fast Reactors, IWGFR/71, Argonne, Ill., June 20-22, 1989

Invited Paper: "Fault-Tolerant Architecture Design," in NSAC/153, Vol. 1, Instrumentation and Controls Strategies for Power Plants, August 1990

\section{R. C. Kryter}

Member, American Nuclear Society

Member, ASME Standard-Preparation Subgroup on LWR Loose-Part Monitoring and Diagnostics

Member, Phi Beta Kappa

Member, Sigma Pi Sigma

Invited Paper: "Use of Motor Current Signature Analysis at the EPRI M\&D Center," H. D. Haynes, R. C. Kryter, B. K. Stewart, Fourth Incipient Failure Detection Conference on Predictive Maintenance for the 90s, Philadelphia, October 15-17, 1990

Society for Technical Communication Award of Merit, "Condition Monitoring of Machinery Using Motor Current Signature Analysis," R. C. Kryter and H. D. Haynes, Sound and Vibration, September 1989

\section{W. Kunselman}

Senior Member, Instrument Society of America

Member, Institute of Certification of Engineering Technicians

\section{T. A. Lewis}

Member, Institute of Electric 1 and Electronics Engineers

Member, Accelerators and Radiation Sources Review Committec 
R. F. Lind

Member, American Society of Mechanical Engineers

Registered Professional Engineer

J. M. Madison

Member, Tau Beta Pi

W. W. Manges

Member, Institute of Electrical and Electronics Engineers

Member, IEEE Computer Society; Vice Chairman, Oak Ridge Section

Registered Professional Engineer

\section{J. March-Leuba}

Best Paper Award, ANS Winter Meeting, Power Division, November 1989

Member, American Nuclear Society; Member, Thermohydraulics Division Program Committee

Reviewer, Nuclear Science and Engineering

Reviewer, Annals of Nuclear Energy

L. C. Maxey

Member, Institute of Electrical and Electronics Engineers

Member, Instrument Society of America

Member, Eta Kappa Nu

Member, Tau Beta Pi

Member, Phi Kappa Phi

D. W. McDonald

Senior Member, Instrument Society of America

Member, Institute of Electricai and Electronics Engineers

Member, IEEE Automatic Controls Society

Member, IEEE Computer Society

Member, Eta Kappa Nu

\section{S. A. McElhaney}

Member, American Physical Society

Member, Sigma Pi Sigma

\section{J. A. McEvers}

Member, Institute of Electrical and Electronics Engineers

Member, IEEE Automatic Controls Society

Member, IEEE Computer Society

Member, Society of Manufacturing Engineers

\section{E. McMillan}

Registered Professional Engineer

\section{J. Meigs}

Member, Institute of Electrical and Electronics Engineers

Member, Eta Kappa Nu 


\section{J. T. Mihalczo}

Fellow, American Nuclear Society; Member, Executive Committee, Nuclear Criticality Safety Divison

Professor, Nuclear Engineering Department, The University of Tennessee, Knoxville Member, Radiation Detection Review Panel, Office of Arms Control, DOE

Invited Paper: "Subcriticality of Two Uranly Nitrate Slab Tanks Spaced in Air by the ${ }^{252}$ Cf-Source-Driven Noise Analysis Method," American Nuclear Society, San Franciso, November 27-30, 1989, Trans. Am. Nucl. Soc. 120-25 (1989)

Invited Paper: "Detector Effects in ${ }^{252} \mathrm{Cf}$ Source Driven Noise Analysis Measurements," American Nuclear Society Meeting, San Francisco, November 27-30, 1989, Trans. Am. Nucl. Soc. 24-30 (1989)

\section{R. Miller}

Senior Member, Instrument Society of America

Member, American Institute of Plant Engineers; Secretary, Local Chapter

Member, Energy Systems Nonexempt Review Committee

Member, ORNL Radioactive Operations Committee

Member, I\&C Division Long-Range Planning Committee

Member, I\&C Division Management Support Team for Females

Co-Chairman, WATTec Presidents Program, 1990

Member, Energy Systems Absence Control PIP Team

\section{G. N. Miller}

Member, Institute of Electrical and Electronics Engineers

Member, Instrument Society of America; Director, Test Measurement Division;

Associate Director, Aerospace Industries Division; Vice President, Local Section

Member, Eta Kappa Nu

Member, Omicron Delta Kappa

Member, Pi Mu Epsilon

Member, Tau Beta Pi

Member, Engineer's Council

Registered Professional Engineer

M. R. Moore

Member, Institute of Electrical and Electronics Engineers

A. C. Morris, Jr.

Member, Institute of Electrical and Electronics Engineers

Registered Professional Engineer, State of Tennessee

\section{J. A. Mullens}

Member, ORNL Scientific and Technical Computing Advisory Committee

\section{J. K. Munro, Jr.}

Member, American Mathematical Society

Member, American Physical Society

Member, IEEE Computer Society

Member, Society for Industrial and Applied Mathematics 


\section{C. Oakes}

ORNL Martin Marietta Corporate Fellow

Fellow, IEEE; Member, National Fellows Committee; Member, Administrative Committec

of the Nuclear and Plasma Science Society; Member, Administrative Committee of the Power Electronics Council; Member, Education Committee; Member, Reactor Instrumentation Technical Committee

Member, American Nuclear Society

Member, ORNL Challenges In Science Seminar Committee

Member, ORNL Distinguished Scientist Selection Committee

V. K. Pare

Member, American Nuclear Society

Member, American Physical Society

Member, Institute of Electrical and Electronics Engineers

D. G. Prater

Member, American National Standards Institute

Member, American Society for Quality Control

Member, Institute of Certification of Engineering Technicians

J. A. Ray

Member, Institute of Electrical and Electronics Engineers

Member, ORNL Electrical Safety Committee

\section{J. Remenyik}

Member, Sigma Xi; Member, Admissions Committee; Member, Nominating Committee Invited Paper: "Variable Time Delay in Dynamic System Simulation," C. L. Carnal and

C. J. Remenyik, Proceedings of the Southeastern Simulation Conference, October 1989

Invited Paper: G. E. Courville, J. O. Hylton, W. P. Murray, A. V. Blalock, and C. J. Remenyik, "Electric Field Probes for Quantitative Moisture Measurements in Building Materials," in Water Vapor Transmission Through Building Materials and Systems, American Society for Testing Materials Standard Technical Publication 1039 (October 1989)

A. W. Renshaw

Member, American Nuclear Society

Member, Society of Women Engineers

Member, Instrument Society of Americ?

\section{W. Ricker}

Member, American Nuclear Society

Member, American Physical Society

Member, Phi Beta Kappa

Member, Sigma Pi Sigma

Member, Sigma Xi

U.S. Member representing ORNL on the American Institute In Taiwan/ Coordination Council for North American Affairs Joint Standing Committee on Civil Nuclear Cooperation 


\section{F. R. Ruppel}

Senior Member, Instrument Society of America; Secretary, Oak Ridge Section Member, American Institute of Chemical Engineers. Computing and Systems Technology Division

\section{G. K. Schulze}

Member, Eta Kappa Nu

Member, Phi Eta Sigma

Member, U.S. NIM-CAMAC Committee

\section{R. L. Shepard}

Senior Member, Instrument Society of America; Lecturer on Thermometry (Short Courses)

Member, American Society for Testing and Materials; Membership Secretary

Member, Institute of Electrical and Electronics Engineers; Member, Program Committec

Member, Sigma Xi

\section{A. A. Shourbaji}

Senior Member, Instrument Society of America

M. L. Simpson

Member, Institute of Electrical and Electronics Engineers

\section{A. Smith}

Technical Advisor, PIF Committee on Alternative Video Formats

\section{O. L. Smith}

Listing in Who's Who in Frontier Science and Technology

Listing in Who's Who in the World

Member, Sigma Xi

Member, Martin Marietta Energy Systems Inventors' Forum

\section{S. F. Smith}

Member, Eta Kappa Nu

Member, Tau Beta Pi

\section{T. Stansberry}

Senior Member, Instrument Society of America

Member, American Society for Training and Development

Member, Iota Lambda Sigma

Member, Maintenance Management Committee - DOE Facilities

Chairman, MAJIC Steering Committee

Member, Martin Marietta Energy Systems Training Committee Subcommittee on Maintenance Training

\section{P. A. Tapp}

Member, Institute of Electrical and Electronics Engineers

Member, IEEE Computer Society

Member, IEEE Instrumentation and Measurement Society

Member, Instrument Society of America 
Member, Eta Kappa Nu

Member, Tau Beta Pi

R. M. Tate

Member, Institute of Electrical and Electronics Engineers

Member, Instrument Society of America

Member, Eta Kappa Nu

Member, Tau Beta Pi

Member, Phi Kappa Phi

Registered Professional Engineer

L. H. Thacker

Member, Phi Beta Kappa

Member, ORNL Graduate Fellow Selection Panel

Member, ORNL Laser Safety Committee

J. H. Todd

Member, Phi Kappa Phi

Member, Sigma Tau

Member, Engineering Physics and Mathematics Division Safety Committee

Member, Tower Shielding Facility Experiment Review Committee

Registered Professional Engineer

R. A. Todd

Registered Professional Engineer

Member, Institute of Electrical and Electronics Engineers

Participant, EMPACT Collaboration of the SSC

Participant, Silicon Electromagnetic Calorimeter Collaboration

R. W. Tucker, Jr.

Senior Member, Instrument Society of America

B. R. Upadhyaya

The University of Tennessee Outstanding Teacher Award, 1990

Senior Member, Institute of Electrical and Electronics Engineers; Liaison Representative,

IEEE Control Systems Society Technical Activities Board on Energy

Senior Member, Instrument Society of America

Member, American Nuclear Society; Member, Book Publishing Comnittee

Member, American Physical Society

Member, American Society for Engineering Education

Registered Professional Engineer

Reviewer, Automatica, Journal of the International Federation of Automatic Control

Reviewer, IEEE Transactions on Automatic Control

Reviewer, IEEE Transactions on Systems, Man and Cybernetics

Reviewer, IEEE Transaction on Neural Networks

Reviewer, Nuclear Science and Engineering

Reviewer, Nuclear Technology

Reviewer, National Science Foundation 
R. A. Vines

Member, Instrument Society of America

B. R. Whitus

Member, Institute of Electrical and Electronics Engineers

Member, Instrument Society of America

Member, Eta Kappa Nu

L. C. Williams

Member, Association for Computing Machinery

Member, Society for Industrial and Applied Mathematics

R. T. Wood

Member, Phi Eta Sigma

Member, Phi Kappa Phi

Member, Tau Beta Pi

Member, ASME Standard-Preparation Subgroup on Internals (Heat Exchangers)

K. E. Wright

Member, I\&C Division Troublebuster Committee

R. W. Wysor

Member, Gamma Beta Phi

Member, Phi Eta Sigma

Member, Phi Kappi Phi

Member, Pi Tau Sigma

Member, Tau Beta Pi

Engineer in Training License

W. D. Zuehsow

Member, Institute of Electrical and Electronics Engineers 


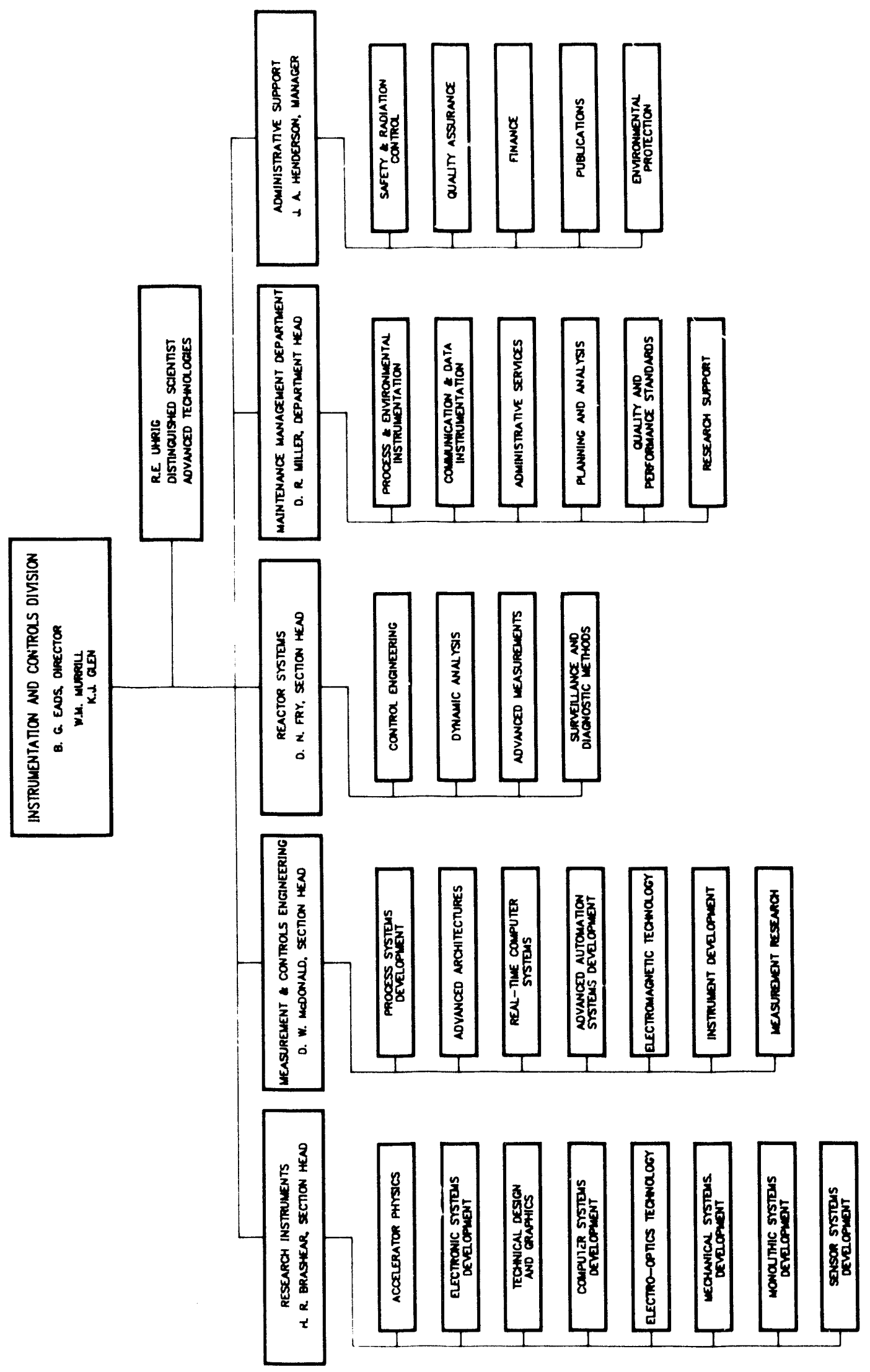




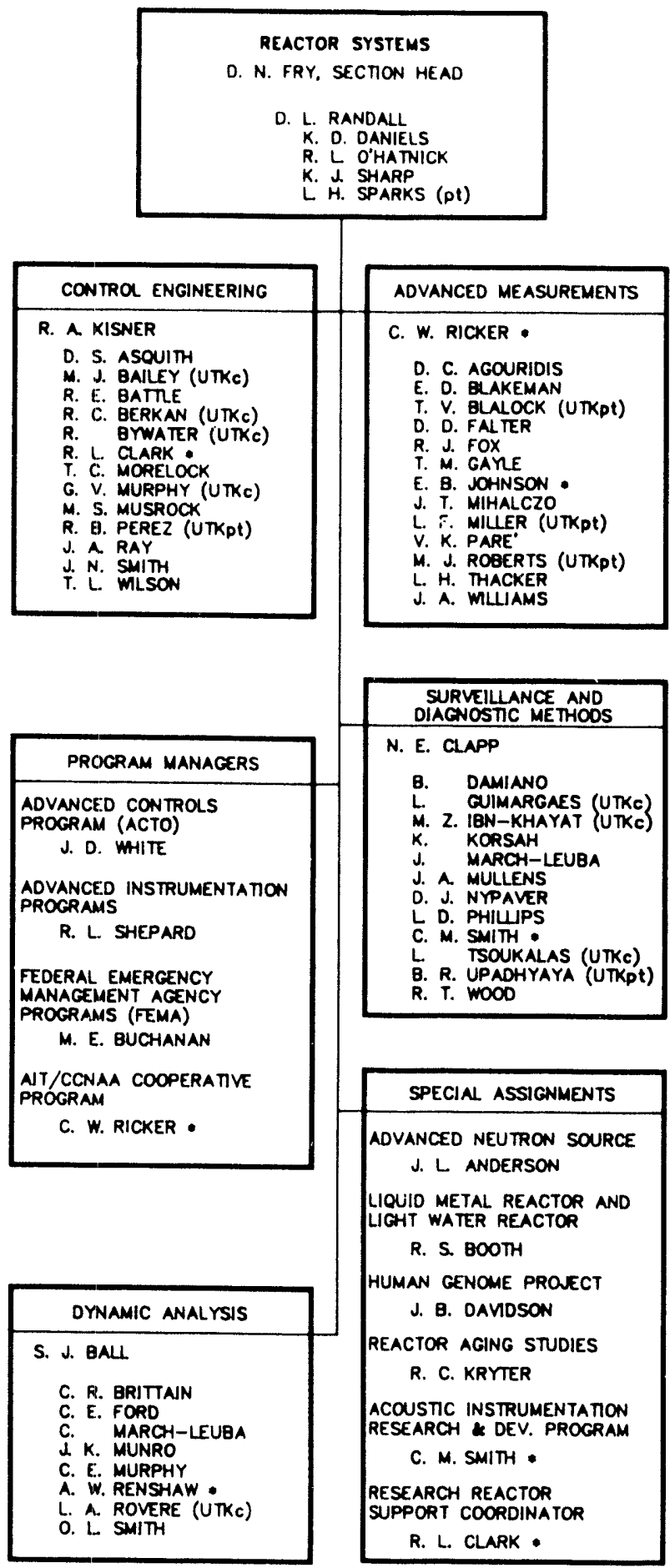

- . . . dual capacity

(Pi) 1 . PART-TIME EMPLOYEE

PART-TIME

(UTKC) . UNIV. of TENNESSEE CONTRACT 


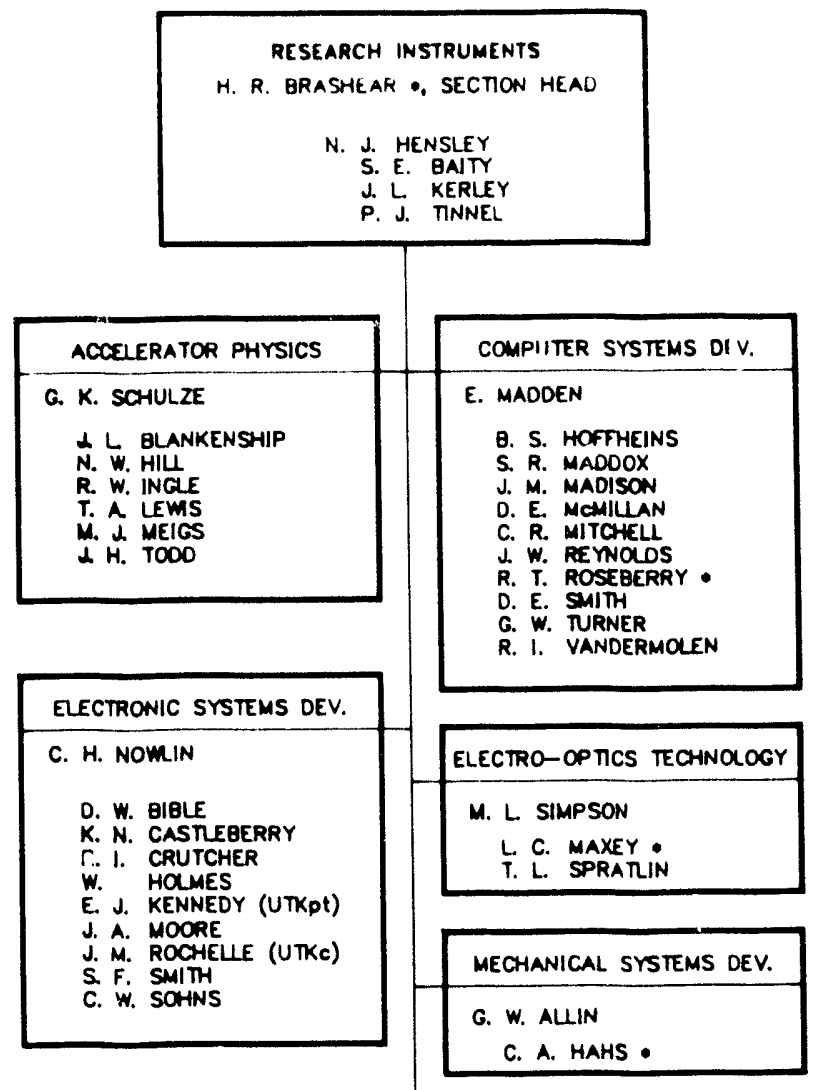

\begin{tabular}{|l|}
\hline $\begin{array}{c}\text { TECHNICAL DESIGN } \\
\text { AND GRAPHICS }\end{array}$ \\
\hline B. P. ADKISSON \\
K. F. CHAPMAN \\
R. E. COOPER \\
M. O. CUTSHAW \\
D. T. HENSLEY (pt) \\
S. M. INMAN \\
R. W. JONES \\
E. C. KEJTH \\
R. A. MAPLES \\
S. A. SHUGART \\
C. E. STEVENSON \\
T. R. SUBICH \\
J. C. TURNER \\
\hline
\end{tabular}

MONOLTTHC SYSTEMS DEV.

G. T. ALLEY •

$$
\begin{aligned}
& \text { D. W. BOULDIN (UTKC) } \\
& \text { C. L. BRITTON } \\
& \text { M. S. EMSRY } \\
& \text { M. N. ERICSON } \\
& \text { K. G. FAL TER } \\
& \text { D. F. NEWFORT (UTKDt) } \\
& \text { R. A. TODO } \\
& \text { A. L. WNTENBERG }
\end{aligned}
$$

PROCRAM MANAGERS DEFENSE ADVANCED
RESEAROH PROJECTS AGENCY
G. T. ALLEY .

$$
\text { G. T. ALLEY • }
$$

MOOULAR ELECTROMAGNETIC LEVTATOR

C. A. HAHS -

NAVY RADIAC DEVELOPMENT

M. L BAUER •

SUPERCONOLLTOR SUPERCOLUDER

H. R. BRASHEAR -

$L \star$

M. L BAUER -

RESEARCH INSTRUMENT MAINT.

C. W. KUNSELMAN .

\begin{tabular}{|l|}
\hline SENSOR SYSTEMS DEV. \\
\hline M. L GAUER - \\
M. M. CHILES \\
C. E. FOWLR \\
S. A. MCEUHANEY \\
V. C. MILIER \\
$\hat{A}$ G MORRIS \\
$\hat{d} . \hat{~}$ RAMSEY \\
K. G. YOUNG \\
\hline
\end{tabular}

\begin{tabular}{|c|}
\hline SPECIAL ASSIGNMENTS \\
\hline HEALTH PHYSICS \\
INSTRUMENTATION UPGRADE \\
W. L BRYAN
\end{tabular}

- . dual capacity

(Pt) ... PART-TIME EMPLOYEE

UTXPI UNIV of TENNESSEE PART- TIME

(UTKC). .UNIY. of TENNESSEE CONTRACT 


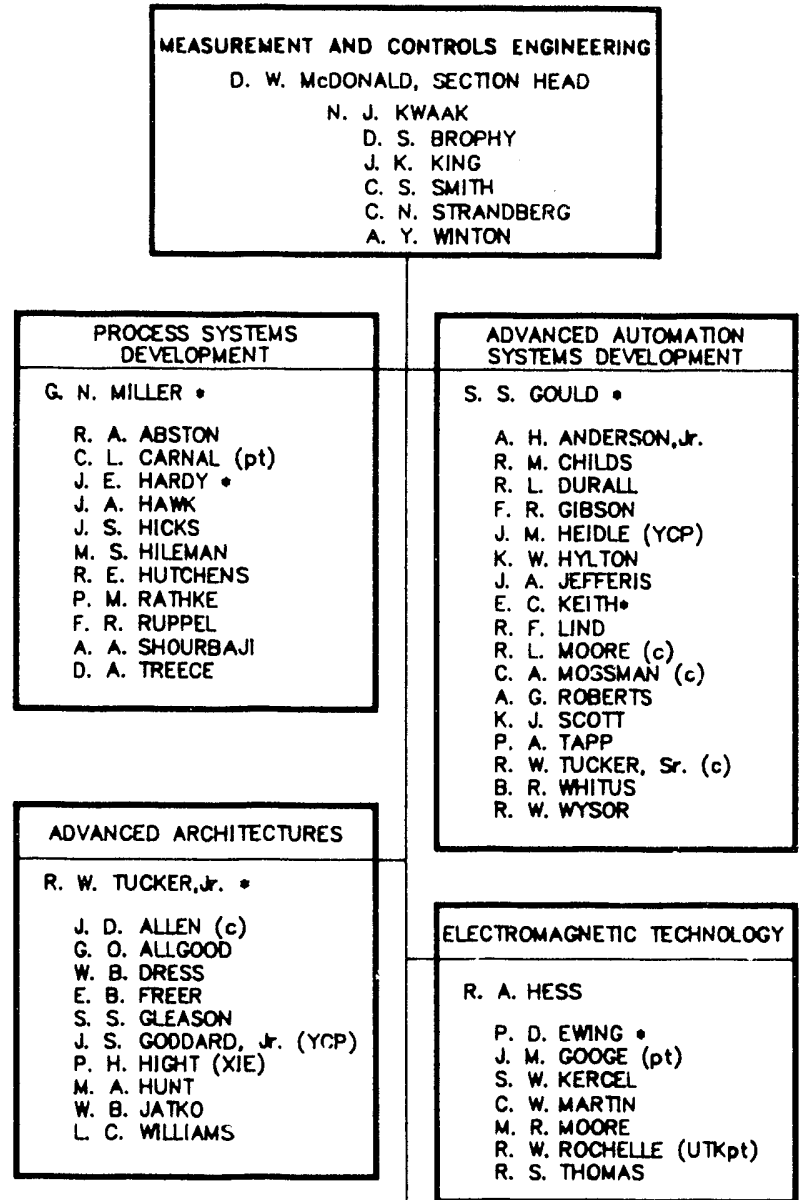

\begin{tabular}{|c|c|}
\hline REAL-TIME COMP. SYSTEMS & INSTRUMENT DEVELOPMENT \\
\hline $\begin{array}{l}\text { J. M. JANSEN.JT. } \\
\text { R. R. BENTZ } \\
\text { B. W. BOMAR (UTSIpt) } \\
\text { J. E. BREEDING } \\
\text { D. A. CLAYTON } \\
\text { J. B. CORDTS } \\
\text { P. B. CRILY (UTKDt) } \\
\text { J. T. GLASSEL } \\
\text { T. P. KARNOWSKI } \\
\text { D. B. KOCH (UTKDt) }\end{array}$ & $\begin{array}{l}\text { J. A. MCEVERS - } \\
\text { W. H. ANDREWS } \\
\text { S. P. BAKER - } \\
\text { A. V. BLALOCK } \\
\text { D. P. GRAHAM } \\
\text { J. W. HALLIWELL } \\
\text { J. T. HUTTON } \\
\text { S. W. MILAM (UTKDt) } \\
\text { R. N. NODINE } \\
\text { K. S. WEAVER }\end{array}$ \\
\hline
\end{tabular}

R. D. LOVELACE

W. W. MANGES

R. M. TATE

G. R. WETHERINGTON, H.*

K. M. WYSOR

W. D. ZUEHSOW

MEASUREMENT RESEARCH

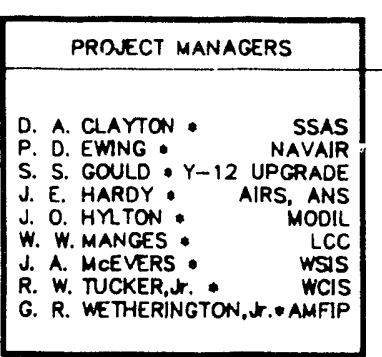

J. O. HRTON *
M. H. COOPER
J. D. LYONS
D. D. MCCUE
T. J. MCINTMRE
T. E. MCKNIGHT
W. P. MURRAY * (c)
C. J. REMENYK (pt)

D. A. CLAYTON

NAVAIR

J. E. HARDY Y

J. O. HYTON * MOOIL

W. W. MANGES : LCC

R. W. MCKER " WCIS

ACOUSTIC MEAS. FACILITY MPROVEMENT PRGM PHASE II

G. N. MILLER *

S. P. BAKER

G. R. WETHERINGTON,4. .

- ... doual capacity

SPij... FAF̂T-TIME MiFLU UTEE

c)..... CONSULTAN Or CONTRACTOR

(UTKPt) UNIV. Of TEI IESSEE PART-TIME

(UTSIPt) . UNIV. Of TEP IESSEE SPACE INST. PART-TIME

XIE) . . INSTRUMENT. TION ENGINEERING, MMES ENG.

YCP) . . COMPUTER APPLICATIONS, MMES ENG. 


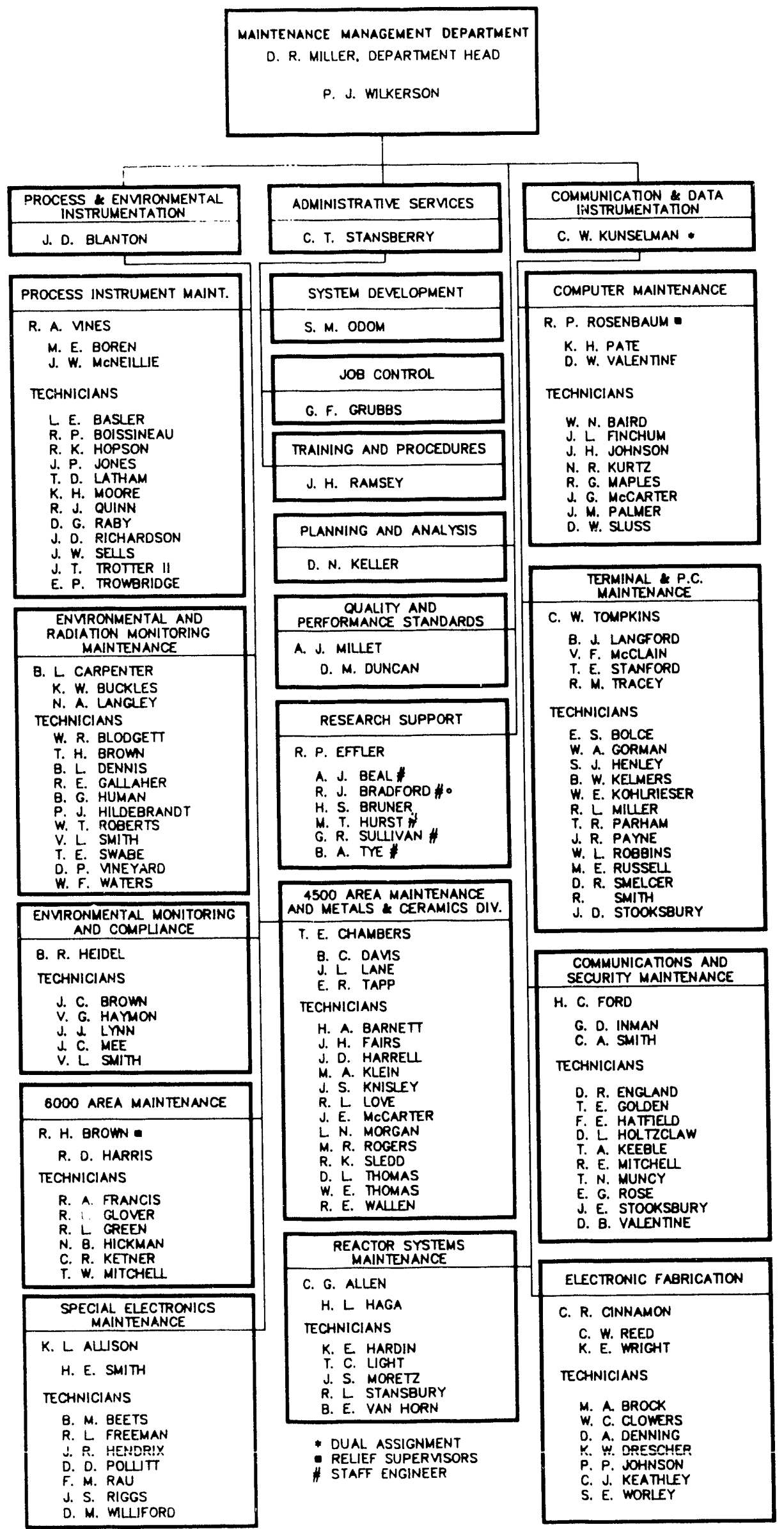




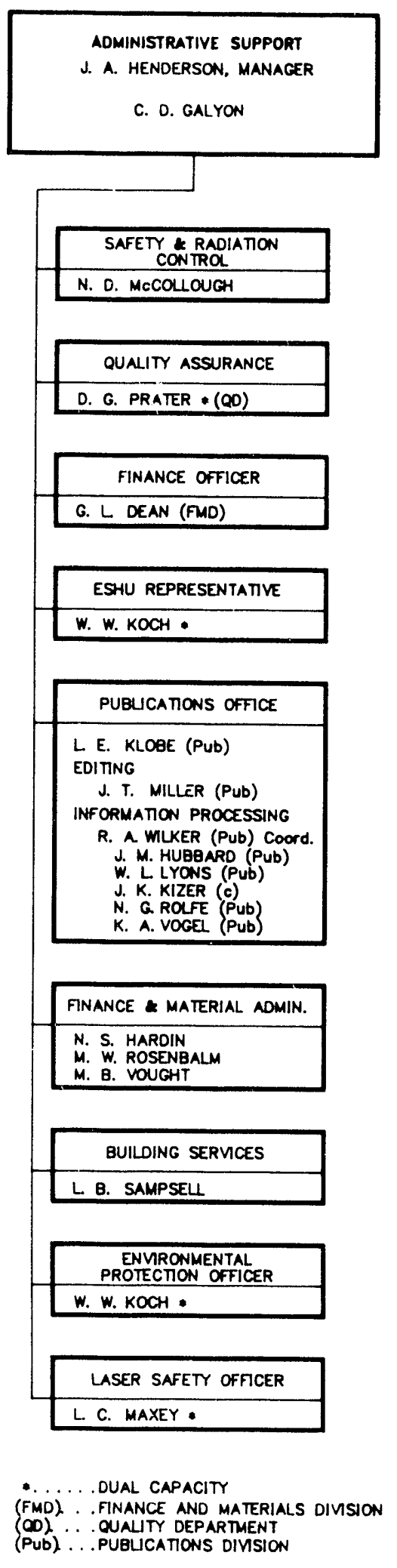


ORNL-6635/V2

Distribution Category UC-506

Instruments, Engineering, and Equipment

\section{INTERNAL DISTRIBUTION}

\begin{tabular}{|c|c|c|}
\hline R. A. Abston & 156. & N. J. Hensley \\
\hline B. P. Adkisson, Jr. & 157. & R. A. Hess \\
\hline D. C. Agouridis & 158. & N. B. Hickman \\
\hline G. T. Alley & 159. & J. S. Hicks \\
\hline G. O. Allgood & 160. & M. S. Hileman \\
\hline G. W. Allin & 161. & B.S. Hoffheins \\
\hline K. L. Allison & 162. & D. L. Holtzclaw \\
\hline J. L. Anderson & 163. & J. M. Hubbard \\
\hline W. H. Andrews, Jr. & 164. & B. G. Human \\
\hline L. D. Anthony & 165. & M. A. Hunt \\
\hline S. P. Baker & 166. & M. T. Hurst \\
\hline S.J. Ball & 167. & J. O. Hylton \\
\hline M. L. Bauer & 168. & K. W. Hylton \\
\hline D. W. Bible & 169. & R. W. Ingle, Jr. \\
\hline T. V. Blalock & 170. & G. D. Inman \\
\hline J. L. Blankenship & 171. & J. M. Jansen, Jr. \\
\hline R. S. Booth & 172. & W. B. Jatko \\
\hline H. R. Brashear & 173. & E. B. Johnson \\
\hline C. R. Brittain & 174. & P. P. Johnson \\
\hline R. H. Brown & 175. & T. A. Keeble \\
\hline T. H. Brown, Jr. & 176. & E. C. Keith \\
\hline W. L. Bryan & 177. & D. N. Keller \\
\hline M. E. Buchanan & 178. & S. W. Kersel \\
\hline T. E. Chambers & 179. & H. T. Kerr \\
\hline M. M. Chiles & 180. & C. R. Ketner \\
\hline N. E. Clapp, Jr. & 181. & L. E. Klobe \\
\hline R. L. Clark & 182. & W. W. Koch, Jr. \\
\hline D. A. Clayton & 183. & K. Korsah \\
\hline M. H. Cooper, Jr. & 184. & E. H. Krieg, Jr. \\
\hline R. I. Crutcher & 185. & R. C. Kryter \\
\hline B. C. Davis & 186. & C. W. Kunselman \\
\hline D. A. Denning & 187. & N. J Kwaak \\
\hline W. B. Dress, Jr. & 188. & T. A. Lewis \\
\hline B. C. Duggins & 189. & R. F. Lind \\
\hline B. G. Eads & 190. & R. L. Love \\
\hline R.P. Effler & 191. & E. Madden \\
\hline P.D. Ewing & 192. & S. R. Maddox \\
\hline J. H. Fairs & 193. & J. M. Madison \\
\hline J. L. Finchum & 194. & W. W. Manges \\
\hline C. E. Ford & 195. & L. C. Maxey \\
\hline C. E. Fowler, Jr. & 196. & J.G. McCarter \\
\hline R. L. Freeman & 197. & N. D. McCollough, Sr. \\
\hline E. B. Freer & $198-297$. & D. W. McDonald \\
\hline D. N. Fry & 298. & S. A. McElhaney \\
\hline R. E. Gallaher & 299. & T. J. McIntyre \\
\hline T. M. Gayle & 300. & D. E. McMillan \\
\hline S. S. Gleason & 301. & J. W. McNeillie \\
\hline R. L. Glover & 302. & M. J. Meigs \\
\hline S. S. Gould & 303. & J. T. Mihalczo \\
\hline N.S. Hardin & $304-333$. & D. R. Miller \\
\hline J. E. Hardy & 334. & G. N. Miller \\
\hline J. D. Harrell & 335. & A. J. Millet \\
\hline J. A. Henderson & 336. & T. W. Mitchell \\
\hline
\end{tabular}




$\begin{array}{ll}337 . & \text { J. L. Moore } \\ 338 . & \text { M. R. Moore } \\ 339 . & \text { T. C. Morelock } \\ 340 . & \text { L. N. Morgan } \\ 341 . & \text { A. C. Morris, Jr. } \\ 342 . & \text { J. A. Mullens } \\ 343 . & \text { T. N. Muncy } \\ 344 . & \text { J. K. Munro, Jr. } \\ 345 . & \text { C. E. Murphy } \\ 346 . & \text { W. M. Murrill } \\ 347 . & \text { R. N. Nodine } \\ 348 . & \text { C. H. Nowlin } \\ 349 . & \text { S. M. Odom } \\ 350 . & \text { R. L. O'Hatnick } \\ 351 . & \text { J. M. Palmer } \\ 352 . & \text { V. K. Pare } \\ 353 . & \text { M. L. Poutsma } \\ 354 . & \text { J. A. Ramsey } \\ 355 . & \text { J. H. Ramsey } \\ 356 . & \text { D. L. Randall } \\ 357 . & \text { P. M. Rathke } \\ 358 . & \text { J. A. Ray } \\ 359 . & \text { C. J. Remenyik } \\ 360 . & \text { A. W. Renshaw } \\ 361 . & \text { J. W. Reynolds } \\ 362 . & \text { C. W. Ricker } \\ 363 . & \text { J. S. Riggs } \\ 364 . & \text { J. B. Roberto } \\ 365 . & \text { A. G. Roberts } \\ 366 . & \text { M. R. Rogers } \\ 367 . & \text { R. T. Roseberry } \\ 368 . & \text { M. W. Rosenbalm } \\ 369 . & \text { R. P. Rosenbaum } \\ 370 . & \text { F. R. Ruppel } \\ 371 . & \text { L. B. Sampsell } \\ 372 . & \text { G. K. Schulze } \\ 373 . & \text { J. W. Sells } \\ 374 . & \text { R. L. Shepard } \\ 375 . & \text { W. H. Sides, Jr. } \\ 376 . & \text { M. L. Simpson } \\ 377 . & \text { R. K. Sledd } \\ & \\ 37\end{array}$

378

379.

380 .

381.

382.

383.

384.

385.

386.

387.

388.

389.

390.

391.

392.

393.

394.

395.

396.

397.

398.

399.

400.

401.

402.

403.

404.

405.

406.

407.

408.

409.

410-412.

413.

414.

415-417.

418.

419.

420.

421-455.

456.
D. W. Sluss

C. M. Smith

D. E. Smith

C. W. Sohns

J. M. Spicer

C. T. Stansberry

L. D. Stinnett

C. N. Strandberg

G. R. Sullivan

P. A. Tapp

L. H. Thacker

R. A. Todd

C. W. Tompkins

R. W. Tucker, Jr.

B. A. Tye

B. R. Upadhyaya

R. E. Upchurch

R. E. Wallen

G. R. Wetherington, Jr.

B. R. Whitus

R. A. Wilker

P. J. Wilkerson

B. Y. Wilkes

J. A. Williams

A. L. Wintenberg

R. T. Wood

K. G. Young

A. Zucker

J. B. Ball (Advisor)

B. Chexal (Advisor)

T. B. Sheridan (Advisor)

R. M. Taylor (Advisor)

Central Research Library

ORNL Y-12 Technical Library

Document Reference Section

Laboratory Records Department

Laboratory Records - ORNL RC

OR NL Patent Section

Program Planning and Analysis Office

I\&C Division Publications Office

ICC Resource Center

\section{EXTERNAL DISTRIBUTION}

\section{U.S. Department of Energy, Oak Ridge, TN 37831}

457. Office of Assistant Manager for Energy Research and Development

458. P. J. Gross, Nuclear Research and Development

459. E. E. Hoffman, Nuclear Research and Development

460. R. E. Williams, Engineering

\section{U.S. Department of Energy, Washington, DC 20548}

461. N. F. Barr, Office of Health \& Environmental Research

462. S. Rosen, Director, Office of Advanced Reactor Programs, NE-45 
463. J. D. Griffith, Office of Associate Deputy Assistant Secretary for Reactor Systems Development and Technology, NE-40

464. R. A. Hunter, Director, Office of Facilities, Fuel Cycle and Test Programs, NE-47

465. N. Grossman, Divison of LMRS and Breeders, NE-452

466. D. J. McGoff, Director, LWR Safety and Technology, NE-42, Office of Reactor Deployment

467. E. E. Purvis, Division of HTGRs, NE-451

468. R. W. Wood, Office of Health \& Environmental Research

\section{U.S. Nuclear Regulatory Commission, Washington, DC 20555}

469. G. A. Arlotto, Director, Division of Engineering Technology

470. R. Bernero, Director, Division of Risk Analysis

471. A. P. D'Zmura, Office of Breeder Reactor Technology Projects, U.S. DOE,

Washington, DC 20545

472. W. S. Farmer, Division of Engineering Technology

473. Carl Johnson, Reactor Risk Branch, DRA

474. W. Morris, Chief of Electrical Engineering Branch, DET

475. G. S. Rhec, Office of Nuclear Regulatory Research

476. G. A. Schwenk, Core Performance Branch, DSI

477. P. M. Williams, Office of Nuclear Regulatory Research

478. Lambros Lois, Reactor Systems Branch, NRR

\section{Tennessee Valley Authority}

479. D. E. Gray, Tennessee Valley Authority, 1300 Commerce Union Bank Building, Chattanooga, TN 37401

480. E. D. Daugherty, Tennessee Valley Authority, 3N78A Missionary Ridge Place, Chattanooga Office Complex, Chattanooga, TN 37402-2801

481. J. Royce Maner, Tennessee Valley Authority, Chestnut Street Towers II, Room 740, Chattanooga, TN 37401

\section{Electric Power Research Institute \\ 3412 Hillview A venue, Palo Alto, CA 94303}

482. Richard Balchizer

483. J. F. O'Brien

484. B. K. Sun

485. Joe Weiss

486. R. W. Colley

487 S. Bhatt

David Taylor Naval Ship Research and Development Center Bethesda, MD 20084

488. F. S. Archibald, Code 194

489. R. J. Boswell, Code 1508

490. R. H. Cantrell, Jr., Code 1905.3

491. K. I. Forman, Code 1925

492. A. J. Henry, Code 1932

493. R. E. Hughes, Code 1502 
494. W. R. Hoover, Code 1930.1

495. D. S. Heydrick, Code 1925

496. G. M. Jebsen, Code 1920.3

497. W. B. Morgan, Code 15

498. W. G. Niner, Code 1932

499. J. F. O'Donnell, Code 193

500. R. V. Reynolds, Code 1932

501. M. M. Sevik, Code 19

502. W. G. Souders, Code 1508

503. J. R. Spina, Code 1946

504. T. B. Thompson, Code 1933

\section{The University of Tennessee, Knoxville, TN 37916}

505. R. K. Adams, Electrical Engineering Department

506. J. A. Euler, Department of Mechanical and Aerospace Engineering

507. R. V. Dubey, Department of Mechanical and Aerospace Engineering

508. J. M. Googe, Mechanical Engineering Department

509. W. L. Green, Electrical Engineering Department

510. T. W. Kerlin, Department of Nuclear Engineering

511. L. F. Miller, Nuclear Engineering

512. C. Moore, Chemical Metallurgy and Polymer Engineering

513. E. C. Muly, Jr., Director, Measurement and Control Engineering Center

514. R. B. Perez, Department of Nuclear Engineering

515. D. Pitts, Mechanical and Aerospace Engineering

516. G. V. Smith, Mechanical and Aerospace Engineering

517. J. E. Stoneking, Acting Head Engineer, Science and Mechanics

518. William T. Sayder, Department of Engineering

\section{Naval Air Systems Command Electromagnetic Environmental Effects Branch, Washington, DC 20361}

519. R. V. Carstensen, Code 5161

520. M. E. Davis, Code $5161 \mathrm{H}$

521. D. E. Fellin, Code $5161 \mathrm{G}$

522. R. A. Hammett, Code 5161C

523. A. J. Iacono, Code 5161B

524. E. G. Lockhart, Code 5161F

525. R. W. Albrecht, University of Washington, Department of Nuclear Energy, Seattle, WA 98195

526. J. D. Allen (Consultant), 10652 Sandpiper Lane, Knoxville, TN 37922

527. J. F. Andary, Code 710.2, Goddard Space Flight Center, Greenbelt, MD 20771

528. M. S. Blair, 7940 Quail Run Road, Knoxville, TN 37938

529. C. J. Borkowski (Consultant), 123 Outer Drive, Oak Ridge, TN 37830

530. T. Braid, Editor of Review of Scientific Instruments, Argonne National Laboratory, Argonne, IL 60439

531. J. Butler, Head, Mechanical Engineering, Naval Explosive Ordnance, Disposal Technology Center, Indian Head, MD 20640

532. J. S. Byrd, E. I. duPont de Nemours and Co., Inc., Savannah River Laboratory, Aiken, SC 29808

533. W. E. Carow, Manager, Oak Ridge Office, Electro-Nucleonics, Inc., Nuclear Operaiions 102 Tuisa Road, Oak Ridge, TN 37830 
534. D. G. Carroll, General Electric Company, 6835 Via Delora, Box 530954, San Jose, CA 95153-5354

535. L. Conway, Dean, College of Engineering, Chrysler Center, North Campus, University of Michigan, Ann Arbor, MI 48109-2092

536. Louis Costrell, National Institute of Standards and Technology, U.S. Department of Commerce, Washington, DC 20234

537. CMDR M. M. Elkins, Code 8153, Naval Electronics Systems Command, Washington, DC 20360

538. EG\&G Ortec, 100 Midland Drive, Oak Ridge, TN 37830

539. LCDR B. Everett, USN, Assistant for Robotics, Department of the Navy, Naval Sea Systems Command, Washington, DC 20362

540. Harold Falkenberry, P.E., Consulting Engineer, 4561 LaSalle Avenue, Alexandria, VA 22304

541. F. L. Fletcher, Energy Technology Engineering Center, P.O. 1449, Canoga Park, CA 91304

542. F. E. Gelhaus, Program Manager, Nuclear Engineering and Operations Department, 3412 Hillview Ave., Box 10412, Palo Alto, CA 94303

543. R. J. Grill, U.S. Department of Justice, Immigration and Naturalization Service, Rm. 2208, 425 I Street NW, Washington, DC 20536

544. J. M. Grover, Hanford Engineering Development Laboratory, P.O. 1970, Richland, WA 99352

545. J. Hord, Director, Center for Chemical Engineering, National Engineering Laboratory, National Institute of Standards and Technology, 325 Broadway, Boulder, CO 80303

546. Beth Jinkerson, University Programs Division, Oak Ridge Associated Universities, Oak Ridge, TN 37830

547. R. G. Julian, Captain, U.S. Air Force, AAMRL/BB A, Wright-Patterson AFB, $\mathrm{OH} 45433$

548. G. F. Knoll, Chairman, Nuclear Engineering Department, The University of Michigan, Ann Arbor, MI 48109-2104

549. Paul Lisowski, Group P-3, MS D449, Los Alamos National Laboratory, Los Alamos, NM 87545

550. R. Mahr, Analytic Disciplines, Inc., 2070 Chain Bridge Road, Suite 400, Vienna, VA 22180

551. C. D. Martin, 4511 Clinch View Lane, Knoxville, TN 37931

552. A. Meintel, MS 152-D, NASA Langley Research Center, Hampton, VA 23665

553. H. G. McCain, Goddard Space Flight Center, Greenbelt, MD 20771

554. A. O. McCoubrey, Center for Absolute Physical Quantities, U.S. Department of Commerce, National Institute of Standards and Technology, Washington, DC 20234

555. Marshall Molen, EE Department Head, Tennessee Technological University, Cookville, TN 38502

556. T. P. Mulcahey, Components Technology, Argonne National Laboratory, Argonne, IL 60439

557. Naval Sea Systems Command, Attention: Code CEL-R, Crystal Plaza \#6, Room 684, Washington, DC 20362-5101

558. D. W. Nolen, Section Head, Equipment Development Division, Aluminum Company of America, Alcoa Center, PA 15069

559. The Nucleus, Inc., 461 Laboratory Road, Oak Ridge, TN 37830

560. Odetics, T. G. Bartholet, 1380 S. Anaheim Blvd., Anaheim, CA 92805

561. Nancy O'Fallon, Applied Physics Division, Building 316, Argonne National Laboratory, Argonne, IL 60439

562. ORAU Technical Library (MERT), P.O. Box 117, Oak Ridge, TN 37830

563. Physics/Optics/Asstronomy Library, 374 Bausch and Lomb Building, University of Rochester, Rochester, NY 14627 
564. J. C. Robinson, Technology for Energy Corporation, 1 Energy Center, Pellissippi Parkway, Knoxville, TN 37922

565. D. A. Rohn, MS 23-2, NASA Lewis Research Center, 21000 Brookpark Road, Cleveland, $\mathrm{OH} 44135$

566. R. L. Rosenfeld, Program Manager, DARPA, 1400 Wilson Blvd., Arlington, VA 22209-2308

567. L. Rubin, Massachusetts Institute of Technology, Francis Bitter National Magnet Laboratory, Building NW14-1108B, Cambridge, MA 02139

568. S. J. Rudnick, Electronics Department Head, Argonne National Laboratory, 9800 South Cass Ave., Building 818, Argonne, IL 60439

569. T. L. Sanders, Division 6323, Sandia National Laboratories, Albuquerque, New Mexico 87185

570. R. F. Saxe (Consultant), Department of Nuclear Engineering, North Carolina State University, Raleigh, NC 27600

571. C. H. Schulman, Manager, Independent Research and Development, Martin Marietta Aerospace, P.O. Box 5837, MP 418, Orlando, FL 32855

572. M. A. Schultz (Consultant), 124 Lakeshore Drive, Apt. QS730, N. Palm Beach, FL 33408

573. C. M. Shoemaker, U.S. A my Human Engineering Laboratory, Aberdeen Proving Ground, MD 21005

574. C. R. Siebentritt, Jr., PO(DC), Federal Emergency Management Agency, Washington, DC 20301

575. R. J. Soulen, Temperature and Pressure Measurements and Standards, Physics Building, National Bureau of Standards, U.S. Department of Commerce, Washington, DC 20234

576. M. L. Stanley, Idaho National Engineering Laboratory, EG\&G, P.O. Box 1625 , Idaho Falls, ID 83401

577. J. A. Thie (Consultant), 12334 Bluff Shore Drive, Knoxville, TN 37922

578. Dr. John Unik, Argonne National Laboratory, 9700 S. Cass Ave., Bldg. 222, Argonne, IL. 60439

579. K. H. Valentine, Science Applications International Corporation, 4161 Campus Point Court Building E, San Diego, CA 92121

580. J. Vranish, Code 716.3, Goddard Space Flight Center, Greenbelt, MD 20771

581. D. K. Wehe, Department of Nuclear Engineering, The University of Michigan, Ann Arbor, MI 48109-2104

582. L. E. Zutovsky, Evaluation Research Corp., 8330 Old Courthouse Road, Vienna, VA 22180

583-706. Given distribution as shown in DOE/OSTI-4500 under Category UC-506, Instruments, Engineering, and Equipment. 

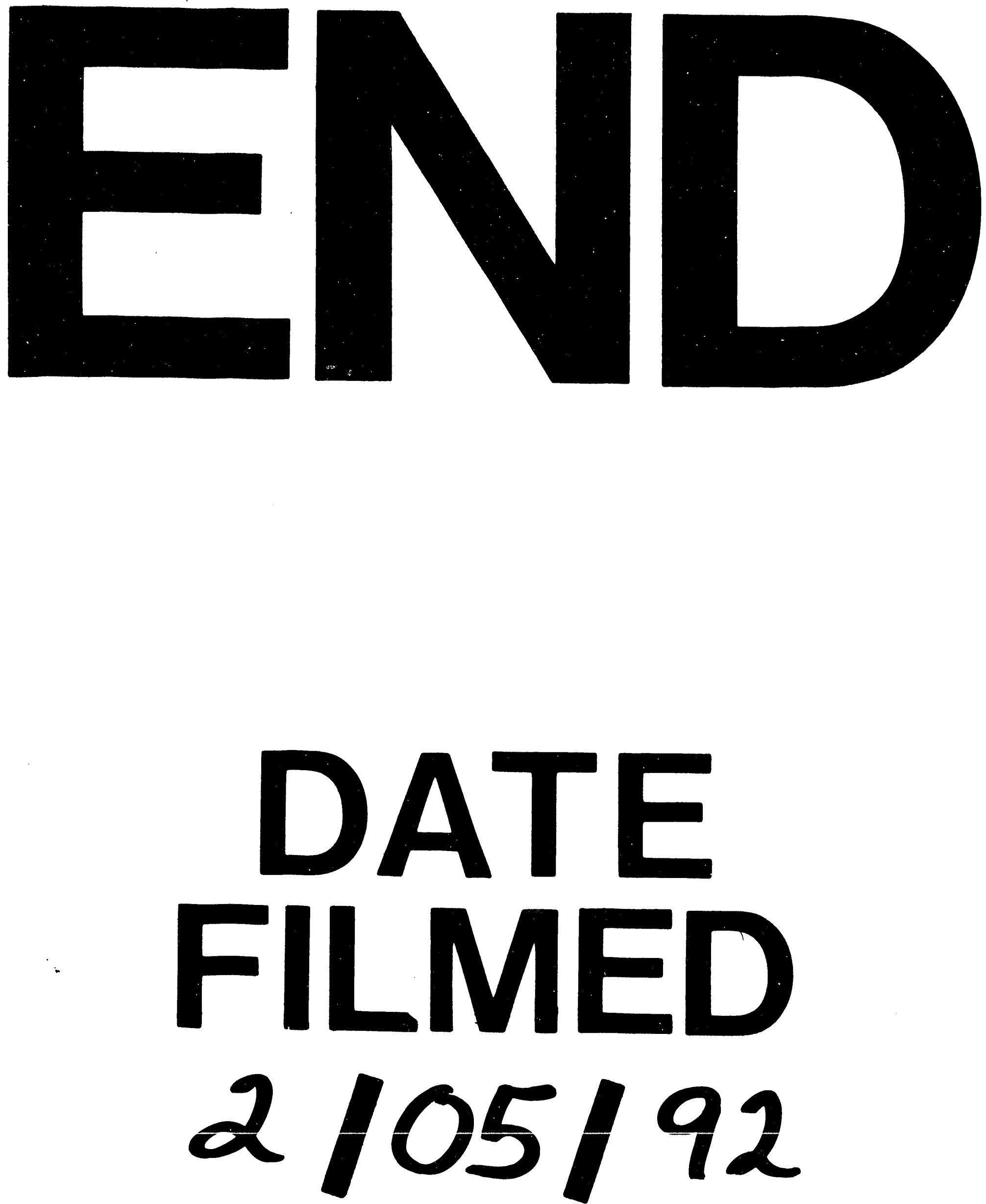
